\title{
A new suoid with tubulidentate, hypselorhizic cheek teeth from the early Miocene of Córcoles, Spain
}

\author{
Martin PICKFORD ${ }^{* *}$ \& Jorge MORALES ${ }^{2}$
}

${ }^{1}$ CR2P/UMR 7207 - Sorbonne Université - MNHN, CNRS, UPMC, Université Paris VI, T.46-56, E.5, case 104, 4 Place Jussieu, 75252 Paris cedex 05, France; martin.pickford@mnhn.fr

${ }^{2}$ Departamento de Paleobiología, Museo Nacional de Ciencias Naturales-CSIC - C/José Gutiérrez Abascal 2, 28006, Madrid, Spain; jorge.morales@mncn.csic.es

* Corresponding author

Pickford, M. \& Morales, J. 2018. A new suoid with tubulidentate, hypselorhizic cheek teeth from the early Miocene of Córcoles, Spain. [Un nuevo suido con dientes yugales tubulidentados e hipselorrizos del Mioceno inferior de Córcoles, España]. Spanish Journal of Palaeontology, 33 (2), 321-344.

\section{ABSTRACT}

Excavations at Córcoles, Guadalajara, Spain (MN 4) in October 1987, yielded a mandible and several isolated teeth of a strange suiform with tubulidentate cheek teeth, initially interpreted to be the remains of Tubulidentata. The specimens are complete enough to remove any doubt about which Order (Artiodactyla) and Superfamily (Suoidea) they belong to. They are here attributed to the Family Doliochoeridae, being related to the genera Bransatochoerus (MP 30) and Lorancahyus (MN 2) both of which have hypsorhizic cheek teeth, the latter with tubules in the teeth, but not to the fully-expressed extent seen in the fossils from Córcoles and the molars retain a distinct and large pulp cavity, which is absent in the Córcoles species. It is inferred that these suoids comprise an evolutionary lineage which went extinct in the early Miocene (ca MN 4b or MN 5) and that the dental specialisations imply ingestion of food to which soil was adhering, which caused excessive abrasion of the teeth, not only occlusally, but also on the lingual aspects of the cheek teeth. Examination of the occlusal and lingual surfaces of the teeth confirm the presence of many pits and large scratches

\section{RESUMEN}

Las excavaciones realizadas en el yacimiento de Córcoles, Guadalajara, España (MN 4) han suministrado una mandíbula y algunos dientes aislados de un extraño suido con los dientes yugales tubulidentados, que inicialmente fueron interpretados como pertenecientes a un Tubulidentata (cerdo hormiguero, Orycteropus). Los ejemplares son lo suficientemente completos como para que no hayan dudas de su pertenencia al Orden Artiodactyla, y dentro de él a la Superfamilia Suoidea. En este trabajo son atribuidos a la Familia Doliochoeridae, relacionándoles con los géneros Brasantochoerus (MP 30) y Lorancahyus (MN 2), ambos con dientes yugales hipsorrizos, éste último género con túbulos dentarios, pero que no alcanzan un desarrollo tan extenso como se aprecia en los fósiles de Córcoles, de manera que los molares aún retienen la cavidad pulpar, que está ausente en la especie de Córcoles. Se infiere que estos suoideos formaron una línea evolutiva que se extinguió en el Mioceno inferior (MN 4 o MN 5) y que la especialización dentaria implicaba la ingesta de comida con particulas del suelo adheridas, lo que causaba una abrasión intensa de los dientes, no solo en el 
on them, in contrast to the buccal and distal surfaces of the teeth which have few scratches or none, respectively.

Keywords: Hyposorhizy, hypselorhizy, tubulidenty, dental adaptations, Suoidea, early Miocene, Western Europe. plano oclusal si no también en la muralla lingual de la serie dental. El examen de las superficies linguales y oclusales de los dientes confirma la presencia de numerosos hoyos y grandes rayaduras, en contraste con las superficies labiales y distales de los dientes que tienen pocas o ninguna rayadura.

Palabras clave: Hyposorrizo, hipselorrizo, tubulidentado, adaptaciones dentales, Suoidea, Mioceno inferior, Europa Occidental.

\section{INTRODUCTION}

The Iberian Peninsula has a rich and extensive Cainozoic fossil record, and over the years it has yielded abundant and varied fossils including many mammals. Its midlatitude position between Africa to the south and the rest of Europe to the north and east is of special significance in that its fossil record preserves evidence of faunal and floral dispersal between the continents (Pickford \& Morales, 1994).

The fossiliferous site of Córcoles, Guadalajara (Fig. 1), was first mentioned by Crusafont \& Quintero (1970) but extensive sampling only took place much later. In the 1980's, excavations at Córcoles yielded a varied assortment of vertebrates (Table 1) (Alférez \& Brea, 1981; Alférez et al., 1981, 1982, 1988a, 1988b, 1999; Maldonado \& Alférez, 1990; Maldonado et al., 1983) including

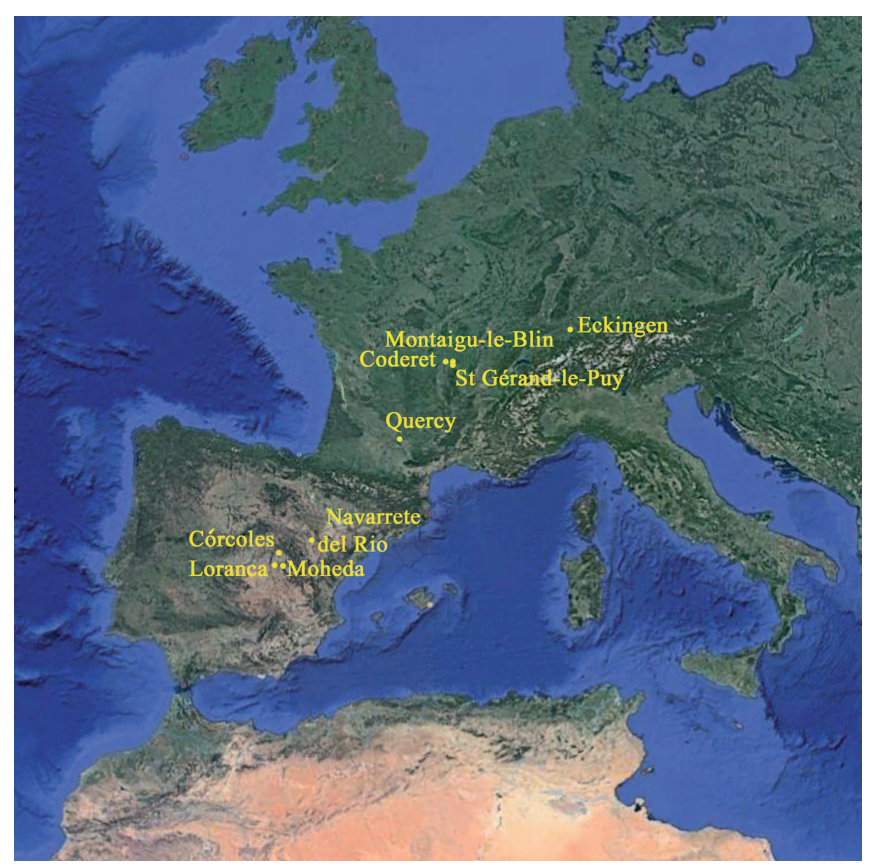

Figure 1. Geographic distribution of Orycterochoerinae. The record from Navarrete del Rio is provisional. gomphotheres, which are among the earliest known from Europe, implying a phase of dispersal of African large mammals into Europe during the early Miocene (MN 4a). In 1987, remains of an enigmatic medium-sized mammal were found, characterised by its tubulidentate cheek tooth structure. A mandible and several isolated cheek teeth were collected and were interpreted by Alférez et al. (1988a, $1988 \mathrm{~b}, 1999$ ) to belong to Tubulidentata (Aardvarks, of which the only surviving example is Orycteropus afer) and the presence of this mammal in the Córcoles fauna was taken to provide additional evidence of mammalian dispersal from Africa into Europe during MN 4. The possibility that the Córcoles material belonged to Suoidea was raised by Pickford (1993) on the basis of some dentognathic similarities that it shares with Lorancahyus, a genus first described from older deposits in Spain (Loranca and Moheda, MN 2) (Figs 1-2).

\begin{tabular}{|c|c|c|c|c|}
\hline Epoch & $\mathrm{Ma}$ & $\mathrm{MN}$ & CORRELATIONS & TAXA \\
\hline & $\begin{array}{l}15 \\
16\end{array}$ & 5 & & \\
\hline \multirow{5}{*}{ 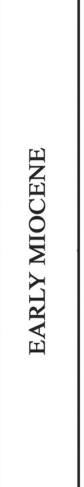 } & & 4 & Córcoles & Orycterochoerus alferezi \\
\hline & 18 & 3 & & \\
\hline & 21 & 2 & $\begin{array}{l}\text { Loranca } \\
\text { Navarrete del Rio }\end{array}$ & \\
\hline & 22 & & $\begin{array}{l}\text { Moheda Montaigu-le-Blin } \\
\text { Quercy }\end{array}$ & Lorancahyus daamsi \\
\hline & 23 & -1 & & \\
\hline OLIGO & 24 & & Eckingen & Bransatochoerus elaverensis \\
\hline
\end{tabular}

Figure 2. Biostratigraphic correlations of European localities that have yielded remains of Orycterochoerinae subfam. nov. 
Table 1. Mammalian fauna associated with Orycterochoerus alferezi gen. et sp. nov. at Córcoles, Spain.

\begin{tabular}{|c|c|}
\hline Lagomorpha & Lagopsis penai \\
\hline «Insectivora» & $\begin{array}{l}\text { Galerix sp. } \\
\text { Amphechinus sp. } \\
\text { Miosorex sp. }\end{array}$ \\
\hline Chiroptera & $\begin{array}{l}\text { Pseudorhinolophus sp. } \\
\text { Genus indet. }\end{array}$ \\
\hline Rodentia & $\begin{array}{l}\text { Megacricetodon primitivus } \\
\text { Democricetodon decipiens } \\
\text { Democricetodon sacedonensis } \\
\text { Ligerimys sp. } \\
\text { Pseudodryomys ibericus } \\
\text { Simplomys simplicidens } \\
\text { Simplomys meulenorum } \\
\text { Simplomys julii } \\
\text { Peridryomys murinus } \\
\text { Microdryomys legidensis } \\
\text { Armantomys aragonensis } \\
\text { Armantomys jasperi } \\
\text { Atlantoxerus cf blacki } \\
\text { Heteroxerus rubricati }\end{array}$ \\
\hline Equidae & Anchitherium corcolense \\
\hline Chalicotheriidae & Phyllotillon naricus \\
\hline Rhinocerotidae & $\begin{array}{l}\text { Hispanotherium matritense } \\
\text { Protaceratherium platyodon }\end{array}$ \\
\hline Cainotheriidae & Cainotherium miocaenicum \\
\hline Suidae & $\begin{array}{l}\text { Eurolistriodon adelli } \\
\text { Listriodon retamaensis }\end{array}$ \\
\hline Doliochoeridae & Orycterochoerus alferezi gen. et sp. nov. \\
\hline Ruminantia & $\begin{array}{l}\text { Dorcatherium crassum } \\
\text { Procervulus dichotomus } \\
\text { Hydropotopsis sp. } \\
\text { Triceromeryx pachecoi } \\
\text { Eotragus artenensis }\end{array}$ \\
\hline Proboscidea & Gomphotherium angustidens \\
\hline Carnivora & $\begin{array}{l}\text { Pseudaelurus quadridentatus } \\
\text { Amphicyon major } \\
\text { Plithocyon armagnacensis } \\
\text { ?Dinocyon thenardi } \\
\text { cf. Alopecocyon sp. } \\
\text { Martes cf. pusilla }\end{array}$ \\
\hline
\end{tabular}

Pickford \& Morales (1998) provided detailed descriptions of peccary-like suoids from Loranca (MN 2b) and Moheda (MN 2a) Spain, which possess hypsorhizic cheek teeth, some with tubular dentine structure in the strongly fused roots, and the authors reiterated the possibility that the Córcoles tubulidentate teeth could belong to Suoidea rather than to Tubulidentata. Pickford (2011, 2016, 2017) described additional fossils of this lineage from St Gérand-le-Puy and Montaigu-le-Blin, France (MN 2, originally attributed to Lorancahyus hypsorhizus by Pickford, 2016) and Pickford \& Hugueney (2018) described suoid fossils from Coderet, France (late Oligocene, MP $30=$ MN 0) (Figs 1-2) which have hypsorhizic teeth with enamel caps that rapidly wear away leaving only the roots as the part functioning during mastication. A peculiar aspect of the Coderet teeth, which are attributed to Bransatochoerus elaverensis (Viret, 1928a) is that they continue to erupt when heavily worn, thereby maintaining the occlusal surface of each tooth at the same level as the other less-worn teeth in the cheektooth battery, unlike most mammals in which heavily worn molars decrease in height relative to the occlusal surface because the roots cease growing after maturity. Bransatochoerus is known from skulls, mandibles and substantial parts of the associated post-cranial skeleton (Pickford, 2016, 2017) and it is evident from the terminal phalanges that it was using its digits to excavate in the soil, perhaps to dig burrows or in search of underground food resources (or both). The types and quantity of heavy wear scars on the cheek teeth (pits, scratches, grooves) attest to the mastication of soil particles with the food.

The available fossil evidence indicates that a small «peccary-like» suoid lineage that existed in Western Europe during the Oligocene, developed hypsorhizic cheek teeth with strongly fused roots (Bransatochoerus, MP 30) which eventually started developing tubular dentine rods within the fused roots (Lorancahyus, MN 2) and which, by MN 4 times (Córcoles) (Fig. 2) culminated in a species with well-developed tubular dentine structure in the cheek teeth and precocious elimination of the enamel caps of the molars. In this lineage, during the life of the individuals, the bulk of mastication of food was achieved by the roots rather than by the dental crowns which wore away at an early age, as was explained by Pickford \& Morales (1998) for Lorancahyus and by Pickford (2016) for Bransatochoerus. The Córcoles suoid continued with this evolutionary trend to such an extent that its cheek teeth superficially resemble those of aardvarks (Alférez et al., 1999). Furthermore, the roots are ever-growing, here defined as hypselorhizic, in contrast to hypselodont teeth in which it is the dental crowns that are ever-growing. An additional feature of this lineage is that the anterior premolars $(\mathrm{p} / 1-\mathrm{p} / 2)$ in the mandible became smaller and smaller over time and did not participate in mastication, as is shown by their diminutive dimensions and gracile morphology and by the persistence of their enamel caps in an unabraded condition in the same jaws in which all the posterior cheek teeth $(\mathrm{p} / 4-\mathrm{m} / 3)$ are worn down to the roots (Pickford, 2016, 2017). The Córcoles mandible shows the same thing, with a completely unworn, reduced and slender $\mathrm{p} / 2$ in the same jaw as heavily worn $\mathrm{p} / 4-\mathrm{m} / 3$. 


\section{MATERIAL AND METHODS}

The fossils described herein are housed at the MGMIGME (Museo Geo-Minero-Instituto Geológico y Minero de España), Madrid. The field numbers commence with the letters CO (for Córcoles). Some of the fossils are housed at the Universidad Complutense, Madrid (UCM $\mathrm{CO}$ numbers) and MNCM-CSIC (Museo Nacional de Ciencias Naturales-Consejo Superior de Investigaciones Científicas).

Images were taken using a Sony Cybershot digital Camera and treated via Photoshop Elements3 to enhance the contrast and to clean the background. Measurements were taken with sliding calipers to the nearest tenth of a $\mathrm{mm}$. Scans were made by the Servicio de Técnicas No Destructivas: Microscopía Electrónica y Confocal y Espectroscopía del MNCM-CSIC, Madrid. Scan Tomographic images were obtained by VGStudio MAX 3.0 software.

\subsection{Designation of tooth position}

The meristic position of the teeth is based on the place of the tooth relative to the occlusal plane which is represented by a forward slash (/). Upper teeth have a capital letter and the merisitic position is above the slash (eg M1/, $\mathrm{P} 4 /)$, lower teeth have a lower case letter and the meristic position is below the slash (eg $\mathrm{m} / 1, \mathrm{p} / 4) . \mathrm{C}, \mathrm{c}=$ canine; $\mathrm{I}$, $\mathrm{i}=$ incisor; $\mathrm{M}, \mathrm{m}=$ molar; $\mathrm{P}, \mathrm{p}=$ premolar.

\subsection{Definitions of tooth morphology and microstructure}

Hypsorhizy is defined as the condition in which the roots of a tooth evolve to become so tall as to take over the function of the enamel-covered crown which wears away completely during the early phase of ontogeny, leaving the root mass as the main functioning occlusal surface during the sub-adult to adult and senile phases of ontogeny. Such roots continue to erupt throughout life at the same rate that the occlusal surface is worn away, thereby maintaining a level occlusal surface. Such roots are usually comprised of the coalescence of individual roots of each tooth into a pillar-like structure which is enveloped in cementum, each root retaining an obvious pulp cavity in its centre, and tapering towards the apices as in normal roots. Such teeth may develop tubular dentinal structures arranged at various angles to the growth trajectory of the roots or the dentine may be structureless.

Hypselorhizy is defined as the condition in which roots of the tooth are ever-growing, as in hyposhizic teeth, but in which pulp cavities no longer occur, and in which the roots do not taper towards the apices as much as in hypsorhizic teeth, thereby forming a pillar in which the mesial and distal surfaces are sub-parallel to each other, as are the buccal and lingual surfaces, for $95 \%$ of the height of the tooth. Such teeth may possess tubular dentine microstructure with the dentine rods packed closely together or spread through a cementum matrix, but where present the dentine rods tend to be oriented parallel to the growth axis of the tooth, imparting a tubulidentate appearance to the tooth.

Tubulidenty is defined as the condition in which the roots of teeth show a rod-like development of the dentine, each rod of which is enclosed in cementum. The dentine rods may be oriented at various angles to the growth axis of the root (in hypsorhizic teeth) or they may all be arranged parallel or sub-parallel to the growth axis (in hypselorhizic teeth). They can also be dispersed within a matrix of cementum (as in premolars) or can be closepacked and extending from the root apex to the occlusal surface of the tooth (as in molars).

\section{LOCATION AND AGE OF CÓRCOLES}

The fossiliferous locality of Córcoles is in Guadalajara Province, Spain (Geological Map Sheet 562 Sacedon) $\left(02^{\circ} 38^{\prime} 46^{\prime \prime} \mathrm{E}: 40^{\circ} 28^{\prime} 06^{\prime} \mathrm{N}\right)$ about $1 \mathrm{~km}$ from the village of the same name (Alférez et al., 1982) (Fig. 1). Originally correlated by the authors to the upper part of MN 4 (Orleanian, MN 4b) it is generally considered to be slightly older, MN 4a, aged about 17 Ma (De Bruijn et al., 1992; Morales et al., 1999) (Fig. 2).

\section{ASSOCIATED FAUNA}

The mammalian fauna from Córcoles comprises the taxa listed in Table 1. There are also diverse invertebrates as well as fish, amphibians, reptiles and birds in the deposits which have been interpreted as marginal lake deposits which accumulated in a lagoon-like setting (Alférez et al., 1999).

Alférez et al. $(1982,1999)$ published a provisional list of the mammalian fauna from Córcoles. Descriptions of the «insectivores» and carnivores from the site have not been published. Other groups in the fauna have been studied as follows: Chiroptera, Alvarez-Sierra et al. (2006); Lagomorpha and Rodentia, Alvarez-Sierra et al. (1994), Crespo (2017), Daams (1990), Daams et al. (1986), DíazMolina \& López Martínez (1979), Freudenthal (2006), García-Paredes et al. (2009), Oliver \& Peláez-Campomanes (2014), Van Der Meulen et al. (2003); Perissodactyla, Iñigo (1993, 1994, 1995, 1997), Iñigo \& Cerdeño (1997); 
Artiodactyla, Alférez et al. (1981), Moyà-Solà \& Alférez (1988), Van der Made \& Alférez (1988); Proboscidea, Maldonado \& Alférez (1990), Maldonado et al. (1983). The record of Pholidota from Córcoles (Alférez et al., 1982) was based on a rib of Anchitherium misidentified as a proximal femur of (?) Teutomanis. There are at least two species of listriodont suids at Córcoles, one of which is close to Eurolistriodon adelli Pickford \& Moyà-Solà, 1995, or Listriodon lockharti; the other was attributed to Listriodon latidens (Van der Made \& Alférez, 1988) but is here considered to represent Listriodon retamaensis Pickford \& Morales, 2003, although some of the larger dental specimens resemble material of Eurolistriodon tenarezensis Orliac (2006) from Montréal-du-Gers, France.

\section{SYSTEMATIC PALAEONTOLOGY}

Order ARTIODACTYLA Owen, 1848

Superfamily SUOIDEA Gray, 1821

Family Doliochoeridae Simpson, 1945

Subfamily Orycterochoerinae subf. nov.

Diagnosis. Doliochoerid suoids with spatulate terminal phalanges, molar roots strongly fused together, hypsorhizic to hypselorhizic molars and fourth premolars, with development of tubulidenty in advanced forms.

Included genera. Lorancahyus Pickford \& Morales, 1998; Bransatochoerus Pickford, 2016; Orycterochoerus gen. nov.

Known distribution. France: Coderet (MP 30), Montaigu-le-Blin (MN 2), St Gérand-le-Puy (MN 2), Quercy (MN 1/2). Spain: Loranca (MN 2), Moheda (MN 2), Navarrete del Rio (provisional identification requires confirmation) (MN 2); Córcoles (MN 4). Germany: Eckingen (MP 30).

Genus Orycterochoerus gen. nov.

Type species Orycterochoerus alferezi sp. nov.

Diagnosis. Medium-sized Doliochoeridae with reduction of the length of the anterior portion of the mandible in front of the $\mathrm{p} / 4$; reduction in dimensions of the $\mathrm{p} / 2$ and $\mathrm{p} / 3$; canine slightly canted laterally, scrofic in section; permanently erupting cheek tooth roots with no pulp cavities (hypselorhizic p/4-m/3, P4/-M3/) with welldeveloped tubular microstructure (m/1-m/3, M1/-M3/) (tubules more weakly developed in $\mathrm{P} 4 /$, almost absent in $\mathrm{p} / 4) ; \mathrm{p} / 4$ with two roots entirely sheathed by a thick layer of cementum to produce a single compressed pillar of ovoid section which, on the buccal side, is concave from radicular apex to occlusal surface; posterior cheek teeth erupt at the same rate that the occlusal part is abraded away by wear, thereby maintaining a level occlusal surface; neighbouring cheek teeth in contact occlusally, but with the radicular apices well-separated from each other; lower teeth concave buccally from occlusal surface to radicular apex, heavy wear on the lingual aspect of the exposed part of the tooth.

Differential diagnosis. Orycterochoerus differs from Lorancahyus and Bransatochoerus by the precocious elimination of the enamel cap of the posterior cheek teeth (p/4-m/3, P4/-M3/) by the reduction of the dimensions of the anterior premolars, the greater shortening of the mandibular ramus anterior to the $p / 4$, the lesser tapering of the roots of the cheek teeth, and the greater splaying out of the cheek tooth root apices in the jaws. In Bransatochoerus and Lorancahyus daamsi, the rear of the symphysis lies beneath the middle of $\mathrm{p} / 2$, whereas in Orycterochoerus it lies beneath the rear of the $\mathrm{p} / 3$; in adult Orycterochoerus $\mathrm{P} 4 /$ is hypselorhizic, without an enamel cap, without pulp cavities, and is single-rooted, $\mathrm{p} / 4$ is the same except that it has two roots internally ensheathed by a thick envelope of cementum to produce a single bucco-lingually compressed pillar-like structure. $\mathrm{P} 4 /$ and $\mathrm{p} / 4$ are significantly smaller than $\mathrm{M} 1 /$ and $\mathrm{m} / 1$ respectively, whereas in Bransatochoerus and Lorancahyus these teeth are of normal suoid morphology (triple- or double-rooted, with pulp cavities in the roots, with enamelcovered crown not greatly shorter or narrower than M1/ or $\mathrm{m} / 1$ respectively). The crown-root profile of the $\mathrm{p} / 4$ of Orycterochoerus is concave buccally, but is more upright in Bransatochoerus and Lorancahyus.

Etymology. Orycterochoerus is a combination of the Greek word Orykter (digger, excavator) and choerus (pig) by analogy with the name of the aardvark (Orycteropus $=$ digger, excavator + foot $)$ an African mammal which similarly possesses tubulidentate cheek teeth.

\section{Species Orycterochoerus alferezi nov.}

Holotype. MGM 6632M (CO 5249a) left mandible containing $\mathrm{c} / 1$, alveolus $\mathrm{p} / 1$, complete $\mathrm{p} / 2$, alveolus $\mathrm{p} / 3$, complete $\mathrm{p} / 4-\mathrm{m} / 3$; (5249b) right mandible fragment (symphyseal area) containing partial alveolus of an incisor, almost complete canine, alveolus of $\mathrm{p} / 1$; (CO 5250), right mandible fragment containing alveolus of $\mathrm{p} / 3$, complete $\mathrm{p} / 4$ and isolated $\mathrm{m} / 1, \mathrm{~m} / 2$; (CO 5251), isolated right $\mathrm{m} / 3$.

Paratypes. MGM 6633M (CO 52--), left and right P4/; (CO 5254), left M1/; (CO 5255), left M2/; (CO 5252), left M3/; (CO 5253), right $\mathrm{M} 2 /$; (CO 5256), right M3/ 
(these teeth are possibly part of the holotype - occlusal fit is good). MGM 6634M (CO 3988), fragment of left mandible containing $\mathrm{m} / 3$; MGM 6635M (CO 433), isolated right $\mathrm{m} / 2 ;$ MGM $6345 \mathrm{M}$, right $\mathrm{p} / 3$. Measurements are provided in Tables 2 and 3.

Post-cranial specimens provisionally attributed to the species. UCM CO 5234, left navicular; UCM CO 5176, proximal end of an axial phalanx. Measurements are provided in Table 4.

Diagnosis. As for the genus; occlusal length of P4/-M3/ measures ca $35 \mathrm{~mm}$ and that of $\mathrm{p} / 4-\mathrm{m} / 3$ ca $37 \mathrm{~mm}$.

Table 2. Dimensions (in $\mathrm{mm}$ ) of teeth of Orycterochoerus alferezi, gen. et sp. nov. from Córcoles, Spain (e - estimated measurement).

\begin{tabular}{clccc}
\hline Catalogue & \multicolumn{1}{c}{ Tooth } & Length & Breadth & Height \\
\hline MGM 6632M & left p/1 alveolus & 2.0 & -- & -- \\
MGM 6632M & left p/2 & 3.5 & 2.2 & 4.0 \\
MGM 6632M & left p/3 alveolus & 4.0 & 2.5 & -- \\
MGM 6632M & left p/4 & 7.0 & 3.3 & 19.0 \\
MGM 6632M & left m/1 & 8.8 & 6.5 & 20.9 \\
MGM 6632M & left m/2 & 10.1 & 7.9 & 20.7 \\
MGM 6632M & left m/3 & 12.2 & 7.5 & 18.6 \\
MGM 6632M & right p/3 alveolus & 4.2 & 1.8 & -- \\
MGM 6345M & right p/4 & 7.0 & 3.7 & 3.5 \\
MGM 6632M & right p/4 & 6.6 & 3.2 & 16.6 \\
MGM 6632M & right m/1 & 8.6 & 6.3 & 19.7 \\
MGM 6632M & right m/2 & 10.6 & 8.0 & 21.1 \\
MGM 6632M & right m/3 & 12.3 & 7.8 & 14.8 \\
MGM 6634M & left m/3 & 11.1 & 7.5 & $17.0 \mathrm{e}$ \\
MGM 6635M & right m/2 & 9.7 & 8.3 & 18.3 \\
MGM 6633M & left P4/ & 4.9 & 5.0 & 12.5 \\
MGM 6633M & left M1/ & 9.1 & 10.2 & 15.4 \\
MGM 6633M & left M2/ & 9.3 & 9.8 & 16.7 \\
MGM 6633M & left M3/ & $12 \mathrm{e}$ & 8.0 & 17.8 \\
MGM 6633M & right P4/ & 5.5 & 5.0 & 11.8 \\
MGM 6633M & right M2/ & $11.8 \mathrm{e}$ & 7.9 & 18.5 \\
MGM 6633M & right M3/ & $12 \mathrm{e}$ & 7.1 & 18.3 \\
\hline & & & & \\
\hline
\end{tabular}

Table 4. Measurements (in $\mathrm{mm}$ ) of post-cranial elements from Córcoles provisionally attributed to Orycterochoerus aleferezi gen. et sp. nov.

\begin{tabular}{lcccc}
\hline $\begin{array}{l}\text { Catalogue, } \\
\text { Specimen }\end{array}$ & $\begin{array}{l}\text { Medio- } \\
\text { lateral } \\
\text { breadth }\end{array}$ & $\begin{array}{l}\text { Antero- } \\
\text { posterior } \\
\text { diameter }\end{array}$ & $\begin{array}{l}\text { Dorso- } \\
\text { palmar } \\
\text { height }\end{array}$ & $\begin{array}{l}\text { Proximo- } \\
\text { distal } \\
\text { diameter }\end{array}$ \\
\hline $\begin{array}{l}\text { CO 5243, } \\
\text { axial phalanx }\end{array}$ & 9.7 & -- & 8.9 & -- \\
$\begin{array}{l}\text { CO 5176, } \\
\text { left navicular }\end{array}$ & 7.7 & 12.7 & -- & 8.3 \\
\hline
\end{tabular}

Etymology. The species name is in honour of Francisco Alférez who excavated the fossils and who pointed out the similarity of the molars to those of Orycteropodidae.

\section{Synonymy.}

Alférez et al., 1988a - Tubulidentados.

Alférez et al., 1988b - Orycteropidae (sic).

Pickford, 1993 - Tayassuidae related to the Loranca tubulident suoid.

Pickford \& Morales, 1998 - Tayassuidae related to Lorancahyus.

Alférez et al., 1999 - Tubulidentados.

Pickford, 2011 - Lorancahyus unnamed species.

Pickford, 2016 - Lorancahyus unnamed species.

Pickford, 2017 - Lorancahyus unnamed species.

Description. The holotype comprises the left horizontal ramus containing $\mathrm{c} / 1, \mathrm{p} / 2, \mathrm{p} / 4-\mathrm{m} / 3$, preserving part of the ascending ramus, and the anterior portion of the right mandible containing the canine and the alveoli for the $\mathrm{p} / 1$ and an incisor (Figs 3-4). There is also a small part of the right ramus preserved containing the $\mathrm{p} / 4$ and there are isolated right $\mathrm{m} / 1-\mathrm{m} / 3$ of the same specimen. A series of isolated upper cheek teeth probably also belong to the same individual, comprising the left $\mathrm{P} 4 /-\mathrm{M} 3$ / and the right $\mathrm{P} 4$ /, $\mathrm{M} 2 /-\mathrm{M} 3 /$. A second individual of the species is represented by a left mandible fragment containing the $\mathrm{m} / 3$, and there is an isolated right $\mathrm{m} / 2$, possibly of the same individual.

Table 3. Dimensions (in mm) of the lower canines of Orycterochoerus alferezi, gen. et sp. nov. from Córcoles, Spain (e - estimated measurement).

\begin{tabular}{ccccccc}
\hline Catalogue & Tooth & Lingual length & Labial length & Distal breadth & Crown height & Root height \\
\hline MGM 6632M & left c/1 & 6.0 & 7.0 & 5.4 & -- & 19.3 \\
MGM 6632M & right c/1 & 5.8 & 7.0 & 5.6 & ca 13 & $18.5 \mathrm{e}$ \\
\hline
\end{tabular}



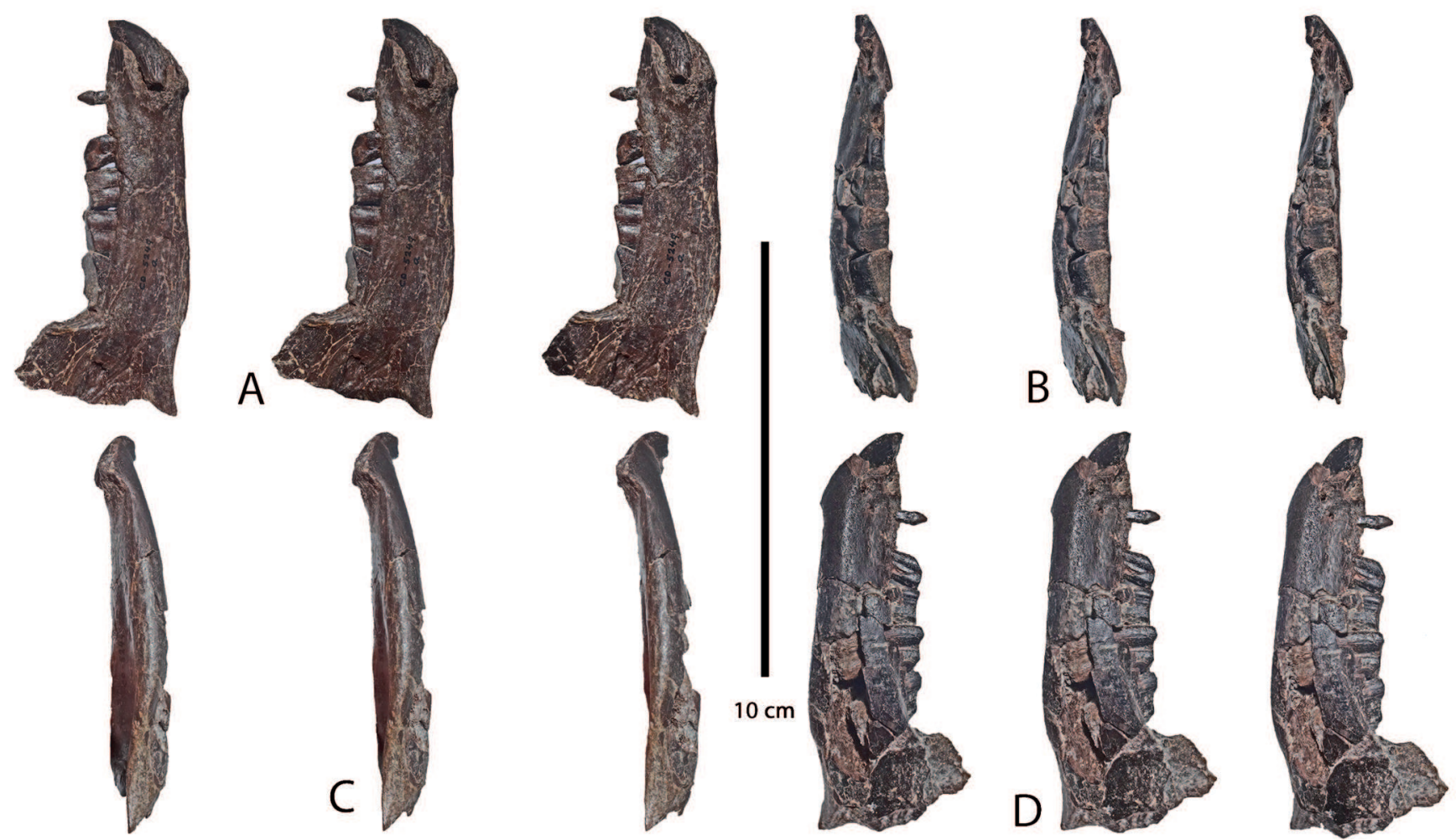

Figure 3. Stereo triplet views of the left mandible (MGM 6632M, CO 5249a), part of the holotype of Orycterochoerus alferezi gen. et sp. nov. from Córcoles, Guadalajara, Spain. Lingual (a), occlusal (b), ventral (c), and buccal views (d).

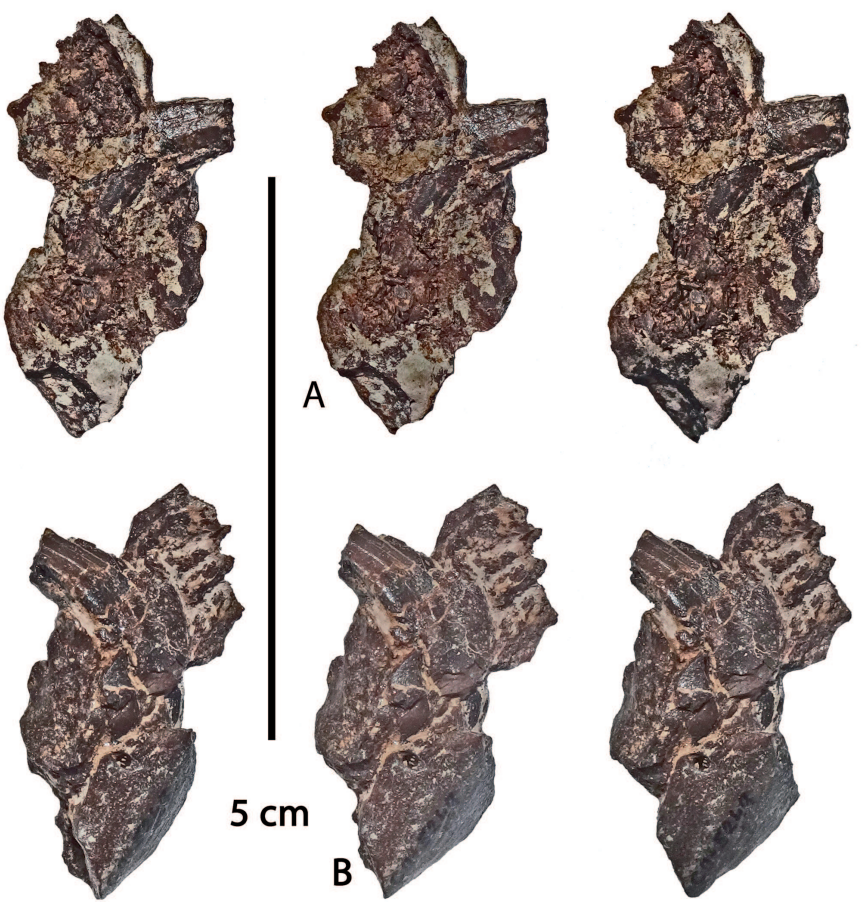

Figure 4. MGM 6632M (CO 5249b), fragment of right mandible containing the $\mathrm{c} / 1$, part of the holotype of Orycterochoerus alferezi, gen. et sp. nov. from Córcoles, Guadalajara, Spain. a) Stereo lingual view. b) Stereo buccal view.
In the lateral view of the left mandible of the holotype, three mental foramina are observed, prominent ones beneath the $p / 1, p / 2$ and a smaller one beneath the front of $\mathrm{p} / 4$ as in Bransatochoerus. The root of the ascending ramus sweeps upwards at a steep angle. The anterior portion of the mandible is relatively short, the distance from the front of the canine to the front of the $\mathrm{p} / 4$ being $20.5 \mathrm{~mm}$ versus $40 \mathrm{~mm}$ for the length of the $\mathrm{p} / 4-\mathrm{m} / 3$. This indicates that the muzzle was greatly reduced in this species, compared to that of other doliochoeres. Despite the facial shortening, there is a diastema $6.9 \mathrm{~mm}$ long between the $\mathrm{p} / 1$ and $\mathrm{p} / 2$, and another one $1.5 \mathrm{~mm}$ long between the $\mathrm{p} / 2$ and $\mathrm{p} / 3$. The $\mathrm{p} / 1$ alveolus is immediately behind the canine. The three anterior premolars are greatly reduced in dimensions, the antero-posterior diameter of the alveolus of the $\mathrm{p} / 1$ being $4 \mathrm{~mm}$, that of the $\mathrm{p} / 2$ being $3.2 \mathrm{~mm}$ and that of the $\mathrm{p} / 3$ being $4 \mathrm{~mm}$. The masseteric fossa is partly preserved on the ascending ramus, its anterior margin lying behind the rear of the $m / 3$. Two flakes of bone have spalled away from lateral surface of the jaw beneath the $\mathrm{m} / 2$ and $\mathrm{m} / 3$ exposing the roots, which are seen to be well-separated at their apices, but in contact with each other at the occlusal surface. Relative to the occlusal plane, the root of the $p / 4$ is slanted anteriorly, that of the $\mathrm{m} / 1$ is almost vertical, that of the $\mathrm{m} / 2$ leans gently distally, while the $\mathrm{m} / 3$ is strongly inclined rearwards. 
In lingual view, the symphysis is seen to be short but extends as far back as the middle of $\mathrm{p} / 3$, the sub-lingual fossa is shallow and terminates anteriorly in a small genial fossa located beneath the radicular apex of the canine. The mandibular foramen in the ascending ramus is observed to lie at the same level as the occlusal surface of the molars, entering the jaw about $12.5 \mathrm{~mm}$ behind the rear of the $\mathrm{m} / 3$. Beneath the foramen, there is a well-marked groove with sharp edges decending obliquely towards the sub-lingual fossa. The ventral margin of the jaw curves gently upwards behind the $\mathrm{m} / 3$ before curving downwards and backwards beneath the mandibular foramen.

In ventral view, the base of the mandible is swollen beneath the $\mathrm{p} / 4-\mathrm{m} / 2$, but is more slender anteriorly and posteriorly. The swollen part of the jaw houses the evergrowing cheek teeth. The exception is the $\mathrm{m} / 3$, which is angled in the jaw, and because its radicular apex ends well above the base of the jaw $(9 \mathrm{~mm})$ the base of the mandible is slender although it is swollen higher up where the $\mathrm{m} / 3$ is housed.

In occlusal view, the two canines are observed to be oriented slightly dihedrally rather than vertically in the jaw as in most other Doliochoeridae, the crowns sweeping gently upwards and laterally at an angle of ca $30^{\circ}$ to the sagittal plane. The inclined alveolus of the $\mathrm{p} / 1$ is immediately behind the canine and it is followed by a short diastema after which there is the vertically implanted $\mathrm{p} / 2$ behind which there is a very short diastema, followed by the $\mathrm{p} / 3-\mathrm{m} / 3$ which form a closed series of teeth. The anterior edge of the ascending ramus is almost vertical.

The base of the mandible indicates that the symphysis was solidly fused.

\section{Dentition.}

Lower teeth. The only evidence about the incisors is preserved in the small fragment of right mandible containing the canine and part of the alveolus of an incisor in the crushed symphyseal part. As preserved the incisor alveolus (?i/3) is almost horizontal, implying a very procumbent orientation of the tooth, but this impression could be partly due to the crushed state of this part of the jaw.

The canines have an elongated root (18.5-19.3 mm deep) which is closed at its apex, and is almost oval in section with an extremely shallow lingual groove. The crown is low, the total height being ca $13 \mathrm{~mm}$ (the apex of the right canine is broken, but the total height can be estimated reasonably accurately). There is a clear cervical demarcation between the crown and the root. In occlusal view the canines are seen to diverge at an angle of ca $30^{\circ}$ from the sagittal plane (i.e. the angle between the canines is about $60^{\circ}$ ) as they sweep upwards and sideways. The distal surface of the crown is almost vertical in side view. The section of the canine at the alveolar margin is scrofic (short lingual side, long labial side, short distal side). The

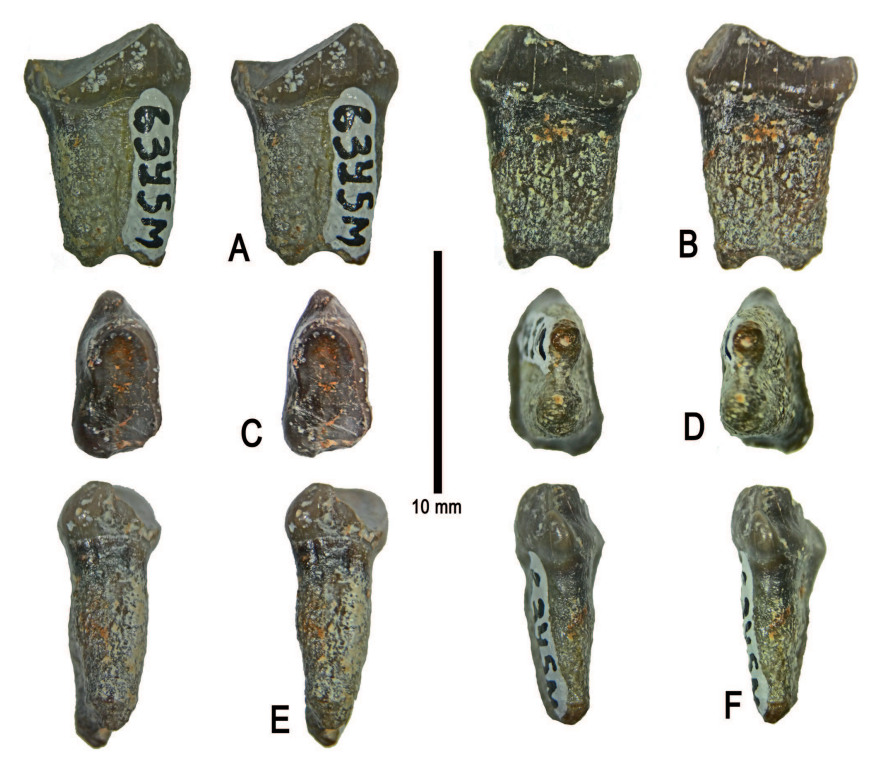

Figure 5. Stereo images of MGM $6345 \mathrm{M}$, right p/4 of Orycterochoerus alferezi from Córcoles, Spain. Buccal (a), lingual (b), occlusal (c), radicular (d), posterior (e), and anterior (f) views.

right canine shows an enamel-free distal surface, but it is not known whether the absence of enamel is due to its removal by abrasion against the upper canine, or whether it had no enamel to start with.

The $p / 1$ is represented only by the left and right alveoli. The dimensions of the alveoli indicate that the tooth was small but damage to the edges precludes accurate measurement.

The $p / 2$ is present in the left mandible. It sits between short diastemata which separate it from the $\mathrm{p} / 1$ and the $\mathrm{p} / 3$. In occlusal view the crown has a bucco-lingually compressed oval outline and is posed on a single buccolingually compressed root with a longitudinal groove on its buccal surface, indicating that it is comprised of two roots which have completely coalesced. Much of the root is exposed above the gingival level because the tooth has risen partly out of its alveolus, as shown in scans. The crown has a shallow distal depression on its lingual side but is otherwise devoid of accessory cusplets. The precristid is steep and rounded, the post-cristid descends steeply distally and is sharper than the pre-cristid.

In the holotype, the $\mathrm{p} / 3$ is represented only by the left and right alveoli, both of which are small and shallow. The depths of the alveoli indicates that, like the $p / 1$ and $\mathrm{p} / 2$, it was not as hypsorhizic as the succeeding premolar and molars which are hypsorhizic.

The $\mathrm{p} / 4$ in the holotype of Orycterochoerus gen. nov. is an extraordinary tooth within a suoid context (Figs 6-7). It is basically a bucco-lingually compressed pillar with an ovoid section, is hypselorhizic and is curved from occlusal surface to radicular apex (concave buccally). A shallow 

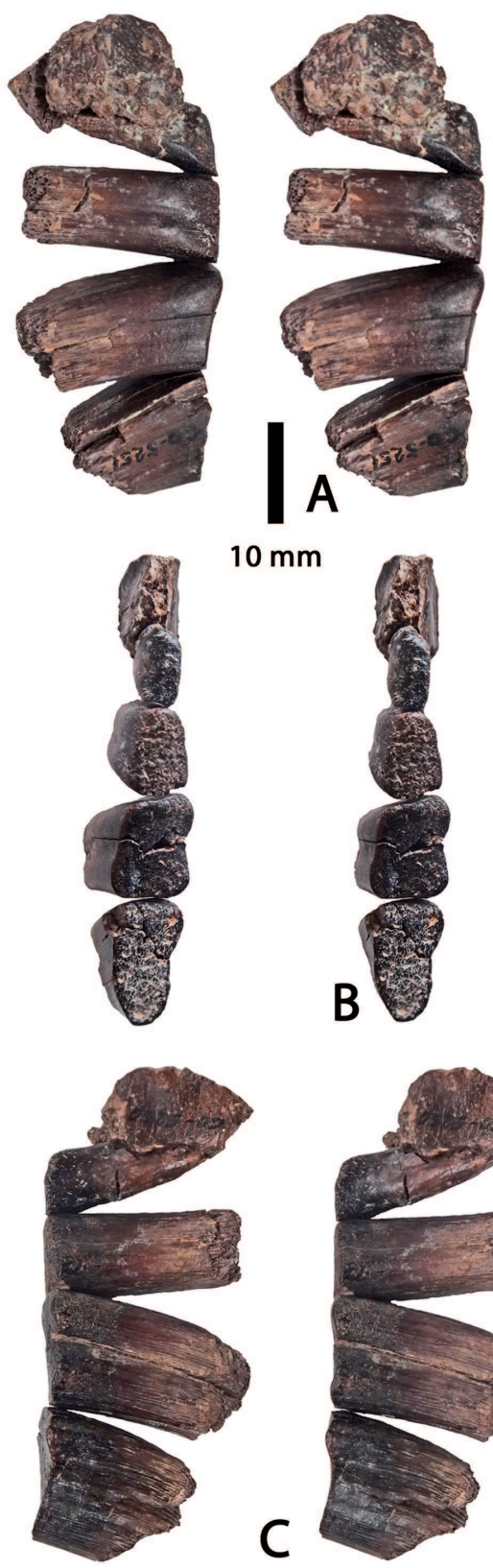

$10 \mathrm{~mm}$
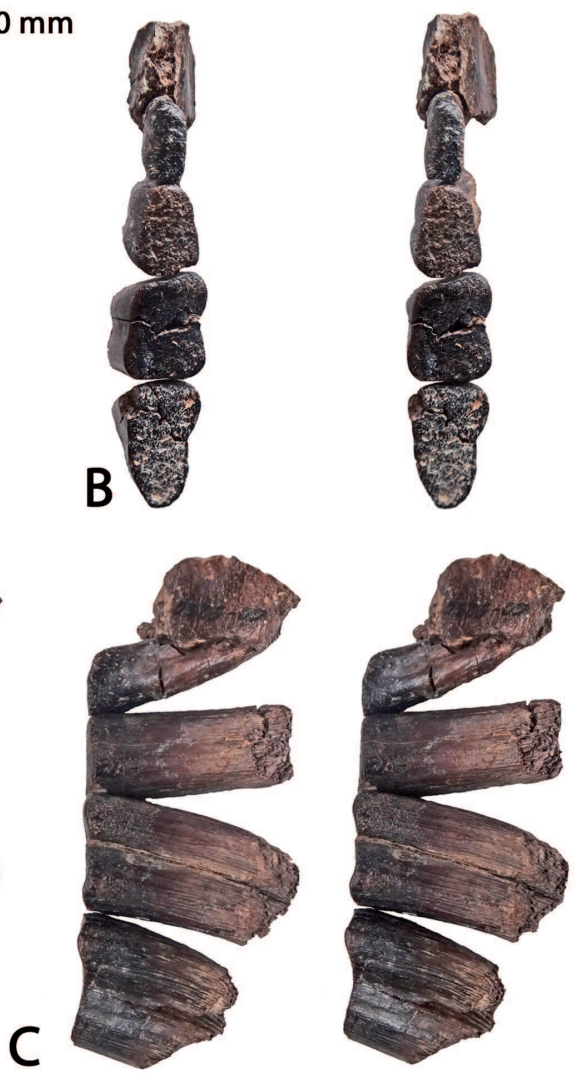

Figure 6. Stereo views of right $\mathrm{p} / 4-\mathrm{m} / 3$, part of the holotype of Orycterochoerus alferezi gen. et sp. nov. from Córcoles, Guadalajara, Spain. (a) Lingual view (note the abraded and polished lingual surface of the $\mathrm{p} / 4$ and m/1). (b) Occlusal view. (c) Buccal view.

longitudinal groove marks the buccal surface. A break in the right $p / 4$ exposes the internal structure in section revealing that the compressed pillar is comprised of two narrow sub-parallel roots completely surrounded by a thick layer of cementum to form a single ovoid pillar. Of the two internal roots, the rear one is slightly smaller in diameter than the mesial one. Each of the roots is marked by a few tiny tubules infilled with dentine separated from each other in a matrix of cementum. The tooth leans backwards in

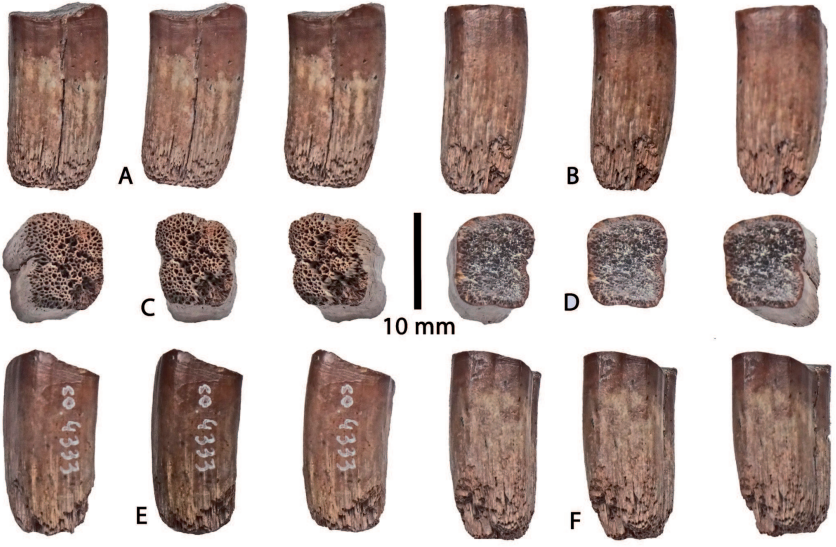

Figure 7. Stereo views of MGM 6635M (CO 4333), isolated right $\mathrm{m} / 2$ of Orycterochoerus alferezi gen. et sp. nov. from Córcoles, Spain. Buccal (a), lingual (b), radicular (c), occlusal (d), mesial (e), distal (f) views.

the jaw, making a large interstitial contact with the $\mathrm{m} / 1$ behind. The apex of its root is far in front of the root apex of the $\mathrm{m} / 1$ which is almost vertical in the jaw.

An isolated right $\mathrm{p} / 4$ (MGM 6345M) has a root that is $6.3 \mathrm{~mm}$ tall, and a crown, as preserved that is $3.5 \mathrm{~mm}$ high (Fig. 5). The crown is covered in enamel, except where heavily worn by a large flat obliquely sloping wear facet. There is a main anterior cusp and a posterior cuspid. The precristid of the mesial cusp is steep and terminates in a low stylid, with a lingual depression behind it. There is a contact facet for the $\mathrm{m} / 1$ at the rear of the tooth. The two roots are almost vertical and have coalesced to form a pillar with an 8-shaped section. The importance of this tooth is that it reveals that the $\mathrm{p} / 4$ of Orycterochoerus has an enamel cap as in other suoids, but that it suffers excessive wear which eventually removes the crown completely, upon which it is the roots that take over the masticatory function.

The $m / 1$ is ovoid in occlusal view, with shallow grooves in the middle of the buccal and lingual surfaces. It is pillarlike in overall construction, with the buccal side slightly concave from root apex to occlusal surface, as in the $\mathrm{p} / 4$ but is slightly less curved. The lingual side is convex. There is no sign of enamel, the occlusal surface being comprised of a dense network of closely spaced, moreor-less vertically arranged, tubules infilled by dentine, the ensemble being enclosed in an envelope of cementum. In radicular view the tubules are still open but are closely packed, and there is a slight gap between two groups of tubular pillars, which indicate that the ancestral state comprised two bucco-lingually fused roots. $1.5 \mathrm{~mm}$ up the tooth, the two groups of tubules are completely coalesced, and above that the envelope of cementum hides the interior, leaving only shallow grooves lingually and buccally to 

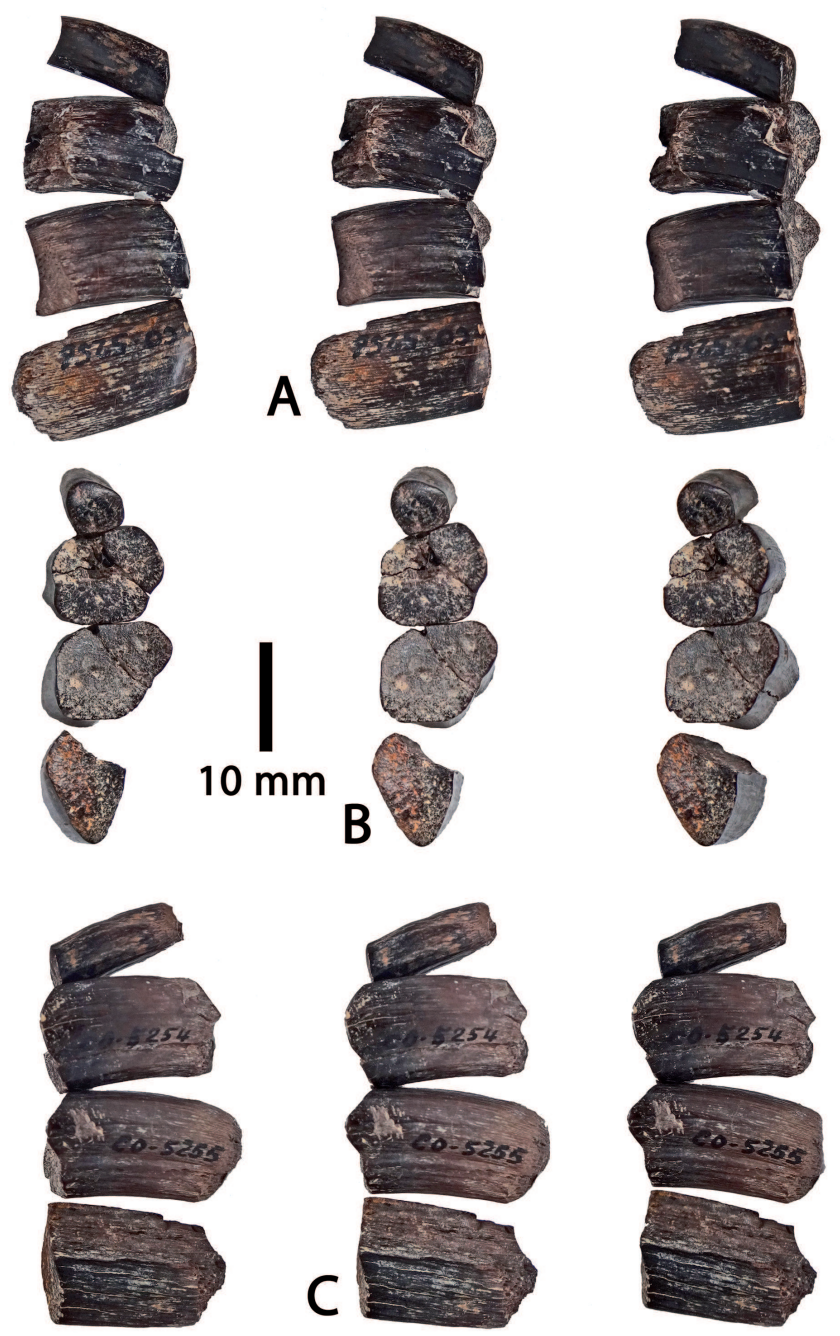

Figure 8. Reconstructed left upper cheek tooth row (MGM $6633 \mathrm{M})$, possibly part of the same individual as the holotype of Orycterochoerus alferezi gen. et sp. nov. from Córcoles, Spain. Lingual (a), occlusal (b), buccal (c) views.

indicate the underlying two-rooted morphology. In lingual view, the $\mathrm{m} / 1$ is implanted vertically in the ramus.

The $m / 2$ is larger than $m / 1$ and differs from it by being more concave along its posterior side, rather than buccally where the bend is slight. Apart from that the basic structure of these two teeth is similar. The $\mathrm{m} / 2$ leans slightly distally in the jaw. In radicular view, two groups of dentine-filled tubules are clearly separated from each other by a narrow transverse gap, but $3.8 \mathrm{~mm}$ up the tooth, the two groups coalesce, above which they are covered in an envelope of cementum which obscures the internal morphology. The lingual and buccal grooves are broader and deeper than in the $\mathrm{m} / 1$, making for a weakly 8 -shaped occlusal outline, but not to the exaggerated extent seen in aardvarks in which the buccal and lingual grooves are considerably deeper and broader (Pickford, 1975) (Fig. 10). Near the

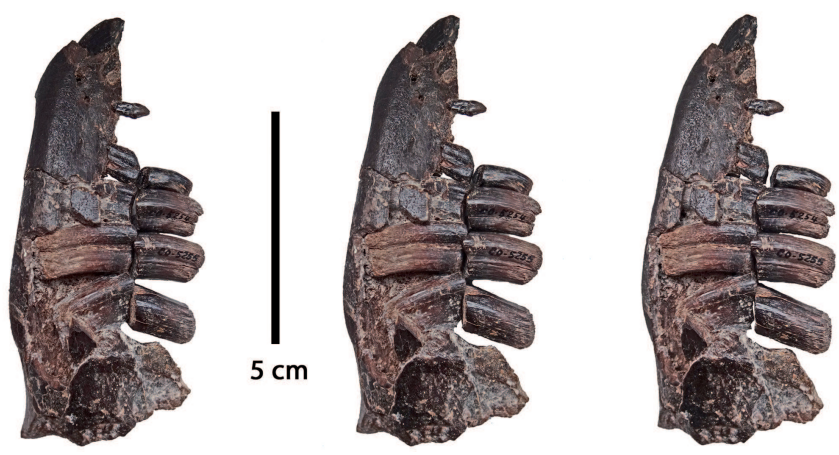

Figure 9. Essay at reconstructing the chewing battery of Orycterochoerus alferezi gen. et sp. nov. from Córcoles, Spain, with upper left teeth occluded with the left mandible, stereo buccal views.

apex of the tooth, there are small interstitial contact facets for the $\mathrm{m} / 1$ in front and the $\mathrm{m} / 3$ behind.

The $\mathrm{m} / 3$ is less tall than the $\mathrm{m} / 2$, and it is narrower bucco-lingually. In occlusal view the tooth narrows distally and has shallow grooves on the buccal and lingual sides, the buccal one being slightly deeper than the one on the lingual side. In radicular view, the tooth is comprised of a dense network of tubules, open apically, but infilled with dentine upwards towards the occlusal surface. The tooth is slightly concave distally, and the tooth is oriented in the jaw at an angle of about $60^{\circ}$ to the alveolar margin. The apex of the root is thus beneath the leading edge of the ascending ramus. Because of this positioning, there is a broad triangular space between the distal surface of the $\mathrm{m} / 2$ and the mesial surface of the $\mathrm{m} / 3$.

Upper teeth. The upper dentition of Orycterochoerus alferezi is less well-represented than the lower one being known only from the P4/-M3/ (Figs 8-9).

The $\mathrm{P} 4 /$ is greatly reduced in mesio-distal $(5.5 \mathrm{~mm})$ and bucco-lingual $(5.0 \mathrm{~mm})$ dimensions, but it is tall $(11.8$ $\mathrm{mm})$. It is basically a tall pillar, ovoid to almost circular in section, which is curved such that the distal surface is concave. In basal view, it is possible to discern abundant open tubules which further up the tooth, right up to the occlusal surface, are infilled with dentine. The pillar so formed is enveloped in a layer of cementum.

The occlusal surface of the M1/ is appreciably bigger than that of the $\mathrm{P} 4 /$ but it is only marginally taller than it. The occlusal outline has a skewed round-cornered rectangular shape. The buccal side has a shallow groove, and the tooth is slightly concave distally. The radicular end is a mass of open tubules arranged into two groups which coalesce towards the occlusal surface, the tubules soon being infilled with dentine right up to the occlusal end. The occlusal surface is comprised of a dense network of infilled tubules surrounded by a sheath of cementum that forms the vertical walls of the tooth. There is no sign of 

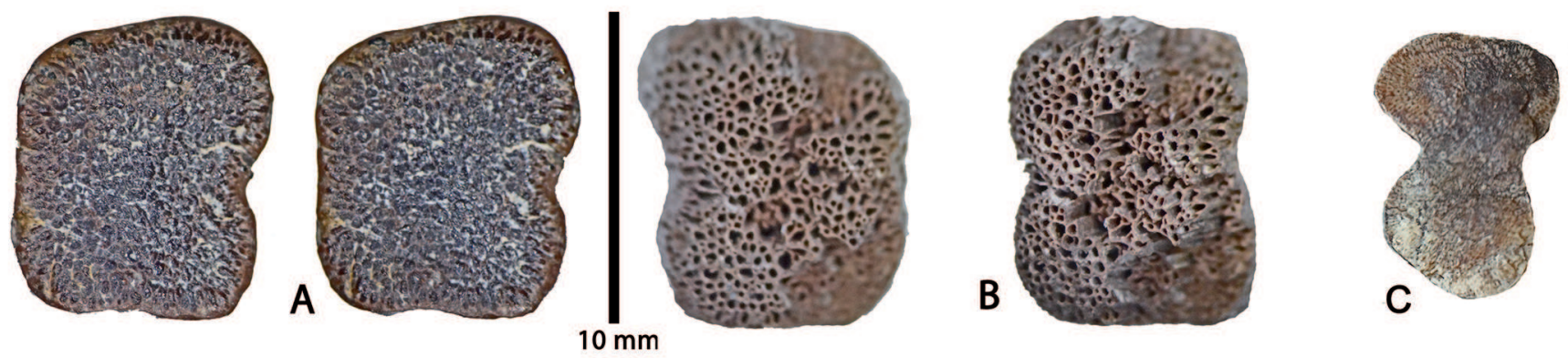

Figure 10. Comparison between molar microstructure of Orycterochoerus (a-b) and an extinct Orycteropodidae (c). Stereo views of the occlusal (a) and radicular (b) ends of MGM 6635M, isolated right $\mathrm{m} / 2$ of Orycterochoerus alferezi gen. et $\mathrm{sp}$. nov. from Córcoles, Spain, to show the tubular structure of the tooth, and the occlusal surface (c) of M2/ of a new genus of Orycteropodidae from Napak, Uganda (Early Miocene). Note the cylindrical structure of the 'tubules' in (c) clearly visible in the upper part of the image.
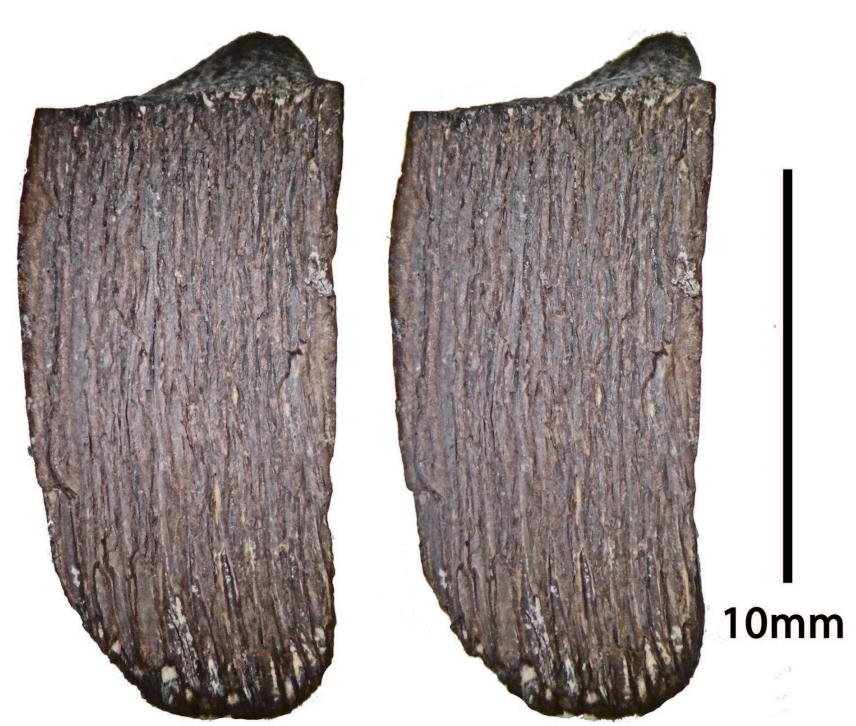

Figure 11. Stereo view of the internal morphology of MGM $6633 \mathrm{M}$, an upper M2/ of Orycterochoerus alferezi, gen. et sp. nov, from Córcoles, Spain, in a naturally broken section, occlusal surface to the top, radicular end at the bottom. Note the whitish deposit (marl) lodged in the open radicular ends of the tubules, which for the rest of the tooth are solidly infilled with dentine.

enamel in this tooth. It has two interstitial contact facets, one for the $\mathrm{P} 4$ / in front and the other for the $\mathrm{M} 2 /$ behind.

The M2/ is appreciably taller than the M1/ but its occlusal surface is almost the same size. Mesially there is a small interstitial facet where it touched the M1/, but distally the contact facet with the M3/ is quite tall, indicating that the M3/ was oriented sub-parallel to the M2/, unlike the lower third molar which lies at a large angle with respect to the $\mathrm{m} / 2$. The basic structure of the $\mathrm{M} 2 /$ is like that of the M1/. A broken surface of the M2/ reveals that the interior of the tooth is comprised of a mass of tall, infilled tubules that extend continuously from the root apex to the occlusal surface, with very slight, irregular deviations from the vertical. The infilled tubules do not appear to bifurcate or anastomose. The outer surface of the tooth is covered in a layer of cementum adorned by low wrinkles which mark the courses of the underlying tubules.

The M3/ is similar to the M2/, not only in occlusal area but also in height, but the tooth narrows distally. Its internal structure is the same as that of the other molars, being comprised of a mass of infilled tubules surrounded by a thin envelope of cementum with vertical wrinkles like those in the other molars.

Dental microstructure. The $\mathrm{P} 4 / \mathrm{-M} 3 /$ and $\mathrm{p} / 4-\mathrm{m} / 3$ of Orycterochoerus are pillar-like structures comprised of masses of closely-applied tubules which are infilled with dentine (Figs 10-11). The outer surface of each pillar is enveloped by cementum. Apart from one $\mathrm{p} / 4$, there is no sign of an enamel cap in these teeth, but whether this is due to its destruction by abrasion or by its non-development is not known, and will remain so until juvenile individuals with unworn teeth are found. The canine and anterior premolars, in contrast, consist of a crown covered in enamel posed on a root, as in other suoids, and so does the $\mathrm{p} / 4$ when it is sub-adult.

The diameter of the dentine tubules in the teeth of Orycterochoerus ranges from 0.42 to $0.30 \mathrm{~mm}$ (15 tubules in a diameter of $6.4 \mathrm{~mm}$ ). In one of the molars examined in detail (MGM 6635M, CO 4333), the smaller tubules tend to be arranged around the periphery of the tooth, there being about 23 along the mesial edge of the right $\mathrm{m} / 2$ which is $7.7 \mathrm{~mm}$ across, and about 21 along its distal edge which is about $7.3 \mathrm{~mm}$ across. In the more central parts of the tooth, which are slightly broader than the mesial and distal ends, there are fewer tubules of slightly greater diameter, there being about 21 tubules across the mesial 


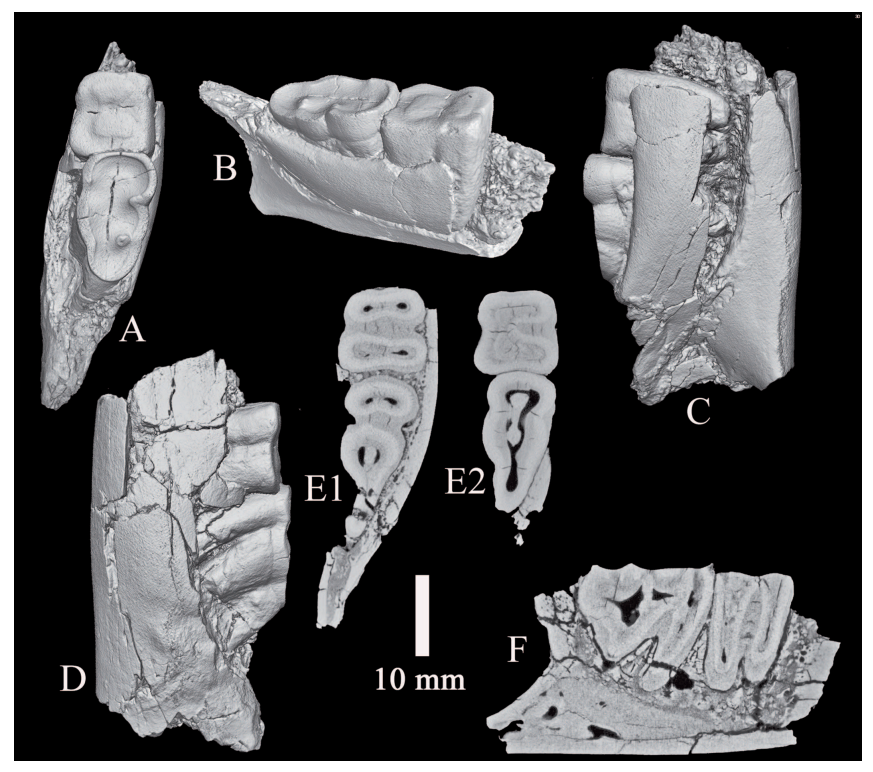

Figure 12. Lorancahyus daamsi from Moheda, Spain, holotype left mandible in various views to show surficial and internal structures. (a) Occlusal view, (b) oblique lingual view, (c) lingual view, (d) buccal view, (e) cross sections of the $\mathrm{m} / 2$ and $\mathrm{m} / 3$ (e1 - immediately beneath the cervix, e2 $-4 \mathrm{~mm}$ beneath the occlusal surface), (f) longitudinal section through the middle of the $\mathrm{m} / 2$ and $\mathrm{m} / 3$. Note the presence of pulp cavities surrounded by layers of dentine of different densities.

half of the tooth $(8.2 \mathrm{~mm}$ broad $)$ and 16 in the distal half (7.8 $\mathrm{mm}$ broad).

In vertical sections studied in naturally broken teeth, the tubules are seen to be empty at the radicular end, but infilled with dentine within a few $\mathrm{mm}$ of the radicular apex, right up to the occlusal surface, and they course from the radicular end to the occlusal surface, not exactly straight, but slightly irregularly. Furthermore, in the more curved teeth (p/4, P4/, m/2) the tubules are also curved to the same extent as the pillar of the tooth.

In all the teeth studied, the outer surface is comprised of a thin cementum envelope up to $0.55 \mathrm{~mm}$ thick, but thinner in places allowing the underlying tubular structure to be expressed in the outer surface of the tooth as low, narrow, vertical striae.

\section{Comparison of radicular microstrucure in} Lorancahyus and Orycterochoerus. The roots of Lorancahyus daamsi shows no sign of the development of tubules (Figs 12-13). Instead the dentine is deposited in layers around the pulp cavities and there is a thick cover of cementum enclosing the roots, to such an extent that the mesial and distal roots of the lower molars are coalescent, and form a single pillar, but showing four pulp cavities, one each beneath the protoconid, metaconid, hypoconid and entoconid. The $\mathrm{m} / 3$ shows a similar situation but there

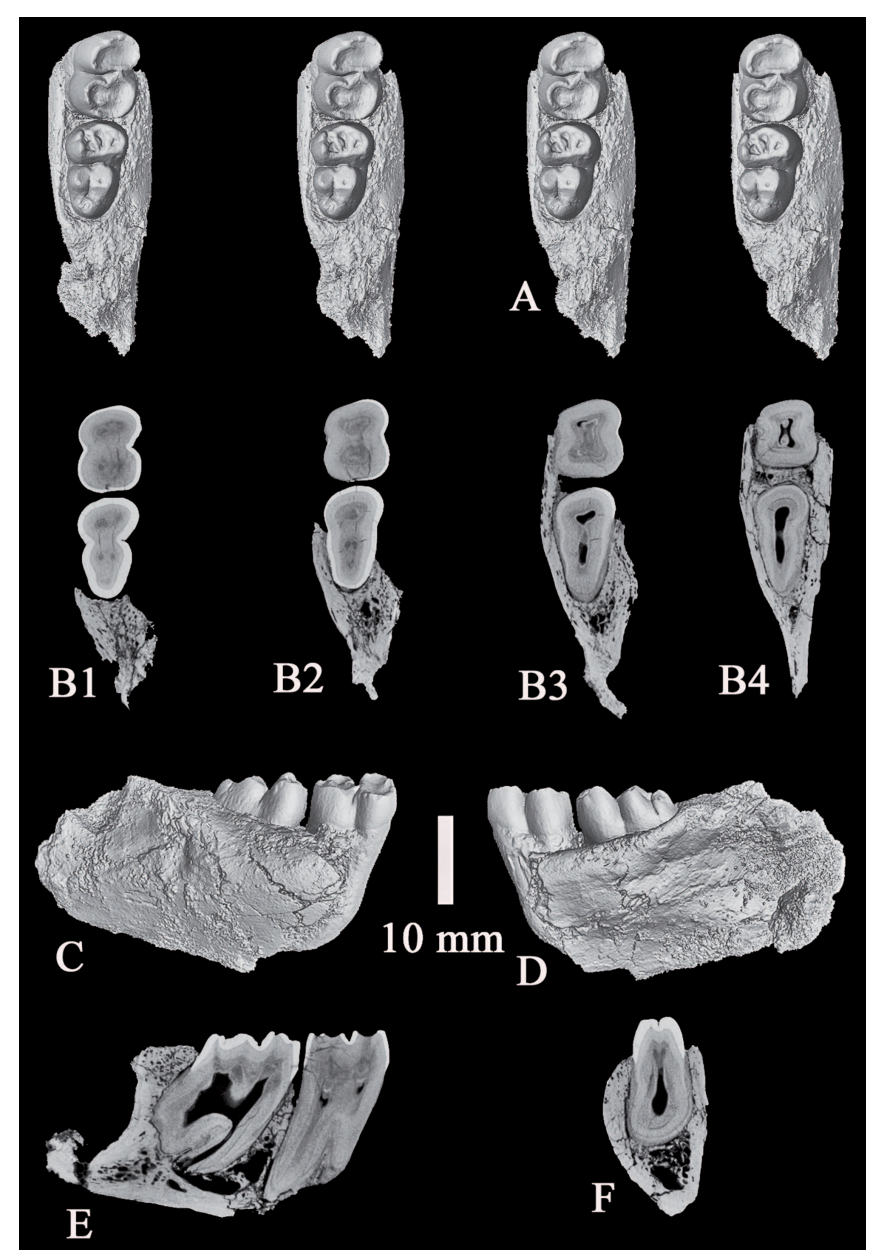

Figure 13. Lorancahyus hypsorhizus, various views of the holotype right mandible from Loranca to show surficial and internal structures. (a) Stereo occlusal views, (b) successive cross sections of the teeth at different depths beneath the occlusal surface (b1 - through the crown, b2 - near cervix, b3 - ca $5 \mathrm{~mm}$ beneath the occlusal surface, b4 - ca $8 \mathrm{~mm}$ beneath the occlusal surface), (c) buccal view, (d) lingual view, (e) longitudinal and transverse sections ( $\mathrm{e} 1$ - longitudinal section through the middle of $\mathrm{m} / 2$ and $\mathrm{m} / 3$, e 2 - transverse section through the mesial half of $\mathrm{m} / 3$ ). Note the presence of pulp cavities in the molars surrounded by layers of dentine of diverse densities.

is a pulp cavity beneath the hypoconulid that is contiguous with that beneath the entoconid and hypoconid.

In Lorancahyus hypsorhizus, the internal structure of the roots is basically similar to that in the older species, Lorancahyus daamsi with concentric layers of dentine round the pulp cavities, all enclosed in cementum. There is one specimen from Loranca however (MNCN LO 3063, $\mathrm{P} 4 /$ ), that shows the development of tubules at various angles (Fig. 16).

In Orycterochoerus alferezi gen. et sp. nov., the entire root system is constructed of tubules infilled with dentine apically, open at the radicular end (Figs 10, 15-17). Large 


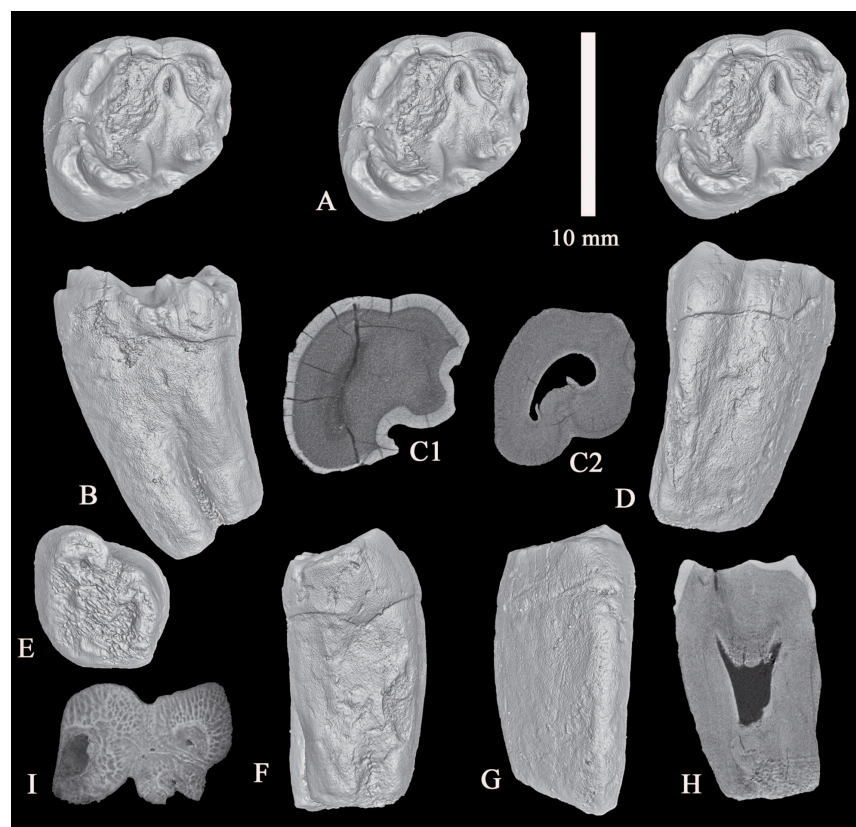

Figure 14. Lorancahyus hypsorhizus upper molar from Loranca in various views to show surficial and internal stuctures. (a) Stereo occlusal views, (b) buccal view, (c) cross sections (c1 - through the crown, c2 - at about half the height of the root), (d) lingual view, (e) radicular view, (f) distal view, (g) mesial view, (h) transverse section through the mesial half of the crown, (i) cross section of a P4/ (MNCN LO 3063) showing tubular dentine microstructure surrounding the pulp cavities. In $\mathbf{a}-\mathbf{h}$, note the presence of a large pulp cavity which is closed at the radicular end of the tooth $(\mathbf{e}, \mathbf{h})$.

pulp cavities no longer exist, the tubules having taken over their function and position. The $\mathrm{p} / 4$ roots are interesting, because they indicate that there are two roots, as in suoids in general, but that these have become coalescent except at the radicular extremity. They too show the development of tubules, but not to the full extent as that observed in the molars.

In summary, the development of tubular root microstructure in Orycterochoerus alferezi has a precursor in Lorancahyus hypsorhizus, where the tubular structure is poorly developed in most teeth, and rather random in one specimen that shows clear tubules. Lorancahyus daamsi shows no tubules at all, but does have coalescent roots and concentric layers of dentine surrounding the pulp cavities.

Dental wear. The right lower canine retains a substantial part of the emergent crown, which shows a vertical wear facet on its distal surface. This surface is enamel-free, but whether the enamel was present and has been worn away, or was never secreted cannot be determined from this specimen.

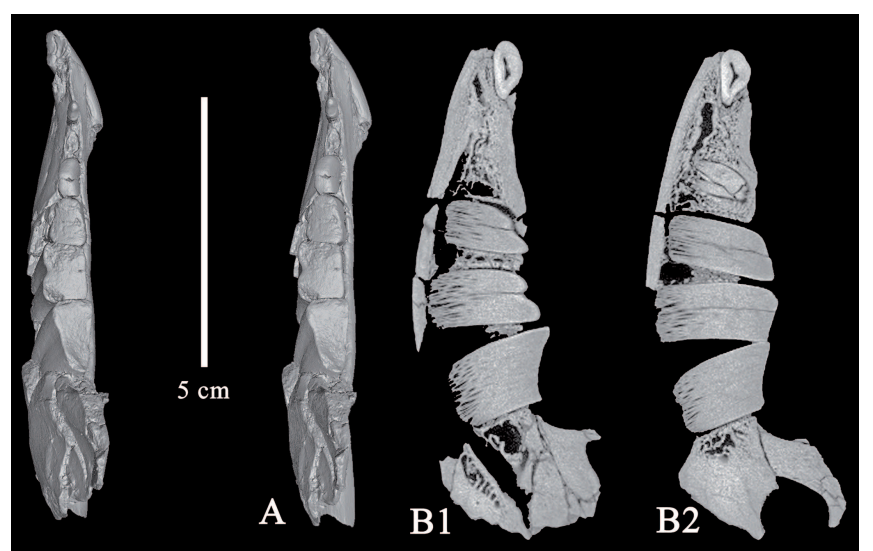

Figure 15. Orycterochoerus alferezi gen. et sp. nov. holotype left mandible from Córcoles in various views to show surficial and internal structures. (a) Stereo occlusal view, (b) parasagittal sections through the mandible, (b1) slightly to the buccal side of the midline of $\mathrm{p} / 4-\mathrm{m} / 3$ (b2) section through the $\mathrm{p} / 4-\mathrm{m} / 3$ and transverse section through the root of the canine. Note the absence of large pulp cavities in the cheek teeth and the presence of a multitude of tubules more or less parallel to the growth axis of the roots. The $\mathrm{p} / 4$ shows two roots which are endowed with a few tubules.

The $\mathrm{p} / 2$ in the holotype is unworn, yet the $\mathrm{p} / 4-\mathrm{m} / 3$ are deeply worn, a fact that indicates that the anterior cheek teeth did not participate in, or were functionally insignificant during, mastication. Their diminutive dimensions indicate the same thing.

In contrast, the $\mathrm{p} / 4-\mathrm{m} / 3$ and $\mathrm{P} 4 /-\mathrm{M} 3 /$ in the holotype and associated material are deeply worn, yet the occlusal surfaces of the teeth remain at the same level (Figs 18-19). This indicates that the teeth are ever-growing, the rate of eruption equalling the rate of abrasion of the occlusal surface. The fact that the posterior cheek teeth in Orycterochoerus have no enamel at all for most of the adult life of the individuals, unlike the geologically older genera Bansatochoerus (Pickford, 2016, 2017; Pickford \& Hugueney, 2018) and Lorancahyus (Pickford \& Morales, 1998) prompts us to define a new category of tooth (hypselorhizy) comprising only the root without any enamel cap, or an enamel cap that is abraded off early during ontogeny, such that for most of the life of the individual it is only the roots that participate in mastication.

Unlike hyoposhizic teeth that retain the pulp cavities throughout life, the posterior cheek teeth of Orycterochoerus are devoid of pulp cavities in the conventional sense of the term. Instead the tubules comprise a swarm of small sub-parallel pulp cavities infilled with dentine and held together by cementum (Fig. 17). Whereas Lorancahyus and Bransatochoerus have been labelled «hypsorhizic» meaning that they retain an enamel crown posed on 


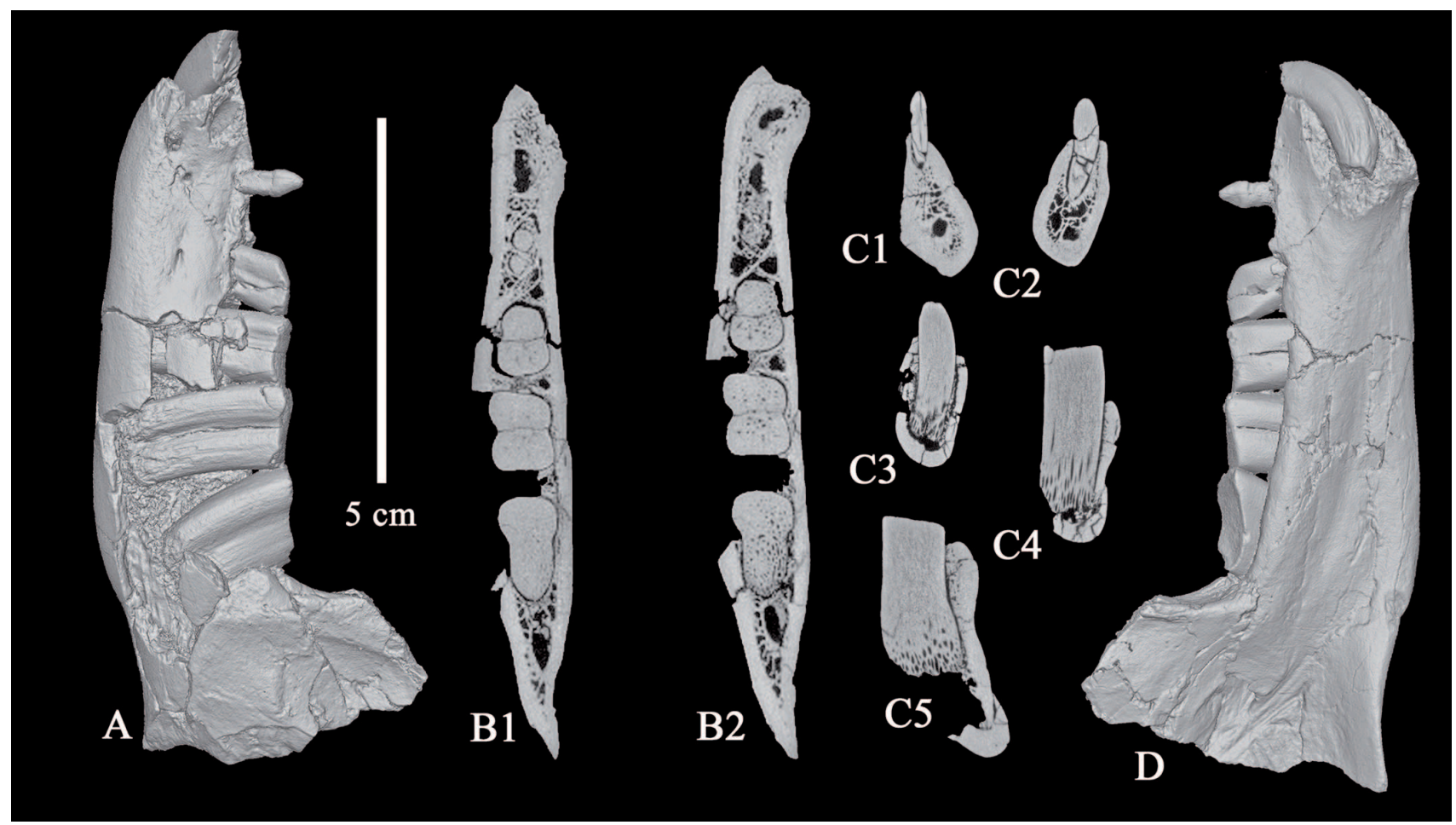

Figure 16. Orycterochoerus alferezi gen. et sp. nov. holotype left mandible from Córcoles in various views to show surficial and internal structures. (a) Buccal view, (b) transverse sections through the mandible, (b1) immediately beneath the gingival plane, (b2) towards the radicular apex of the $\mathrm{m} / 3$. (c) Cross sections through successive teeth $(\mathbf{c} 1-\mathrm{p} / 2 ; \mathbf{c} 2-\mathrm{p} / 4 ; \mathbf{c 3}-$ $\mathrm{m} / 1 ; \mathbf{c} 4-\mathrm{m} / 2 ; \mathbf{c 5}-\mathrm{m} / 3$ ). (d) Lingual view.

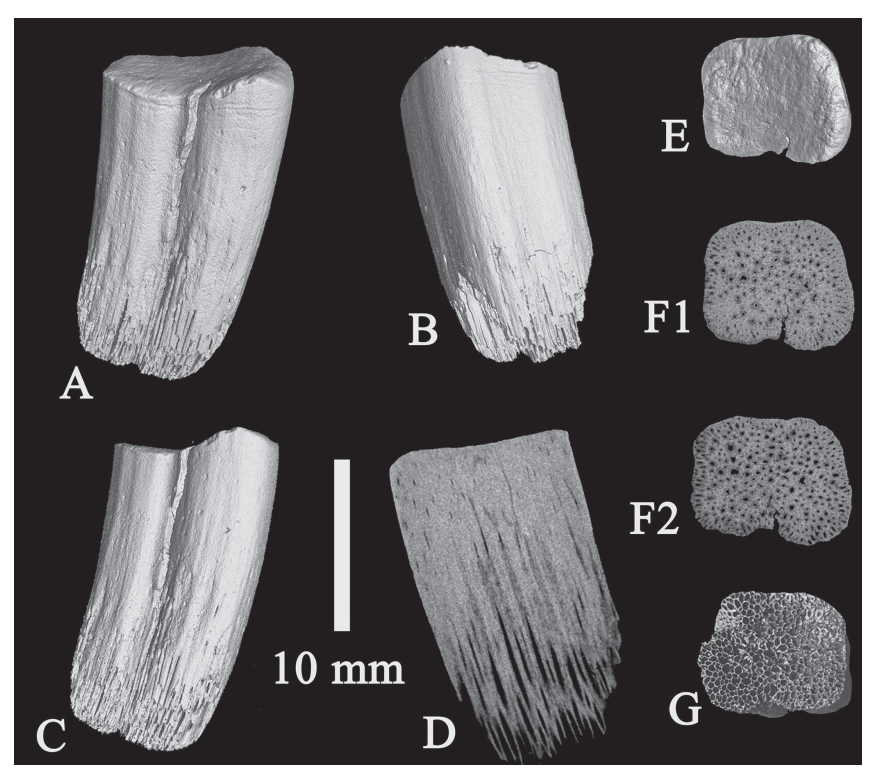

Figure 17. MGM 6635M right $\mathrm{m} / 2$ of Orycterochoerus alferezi gen. et sp. nov. from Córcoles, to show surficial and internal structures. (a) Oblique occluso-buccal view, (b) oblique mesio-lingual view, (c) buccal view, (d) longitudinal view through the middle of the tooth, (e) occlusal view, (f) transverse sections (f1 - ca $4 \mathrm{~mm}$ beneath the occlusal surface of the tooth, $\mathbf{f} 2$ - ca 10 $\mathrm{mm}$ beneath the occlusal surface), (g) radicular view. Note the absence of pulp cavities and the multitude of tubules which are open at the radicular end, but filled with dentine apically. tall, fused roots and have pulp cavities, the teeth of Orycterochoerus can be called «hypselorhizic» with the connotation that the roots are ever-growing with no pulp cavity, and that for most of the sub-adult and adult life of the individuals, mastication is carried out by the root mass of the teeth, the crown being eradicated at an early ontogenetic phase.

Under the microscope, the occlusal surfaces of the fourth premolars and the three molars are observed to comprise a network of tubules infilled with dentine, the ensemble being ensheathed in a layer of cementum. The infillings of the tubules (dentine) are slightly more resistant to wear than the tubule walls (comprised of cementum) with the result that the occlusal surface of the teeth has an irregular low relief topography, the hills being dentine and the valleys cementum.

In detail, it can be seen that the lingual surfaces of the $\mathrm{P} 4 /-\mathrm{M} 3 /$ and the $\mathrm{p} / 4-\mathrm{m} / 3$ are heavily abraded, to the extent of exposing some of the tubular structures beneath the cementum envelope that covers the outer surfaces of the tooth (Fig. 19). Examination under a microscope reveals the presence of large pits and scratches affecting the occlusal and lingual surfaces of the $\mathrm{p} / 4, \mathrm{~m} / 1$ and succeeding teeth, probably caused by impacts between the occlusal surfaces of the teeth and grit particles in the food during mastication. The distal and buccal surfaces of 

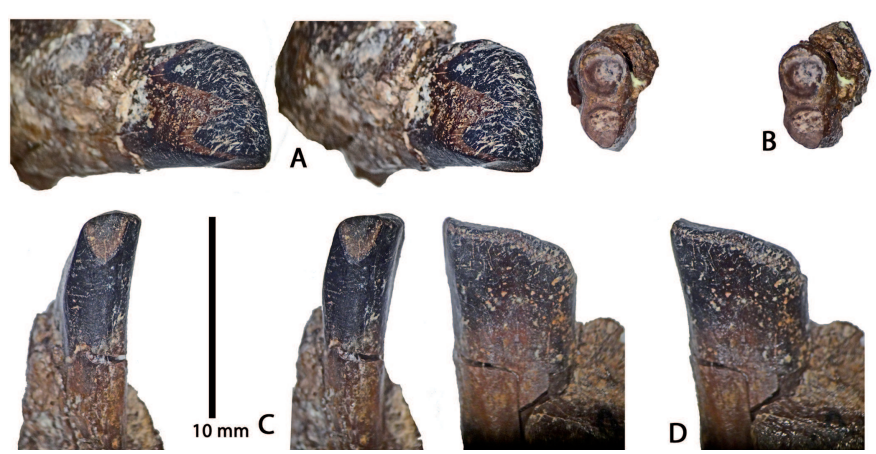

Figure 18. Stereo views of MGM $6632 \mathrm{M}$, right p/4 of Orycterochoerus alferezi, gen. et sp. nov. from Córcoles, Spain, to show abrasion of the occlusal and lingual surfaces of the tooth. (a) Oblique linguoocclusal view showing heavy abrasion with pits and gouges (infilled with pale marl), (b) radicular view to show two-rooted internal structure enveloped in cementum to produce a single bucco-lingually compressed pillar-like tooth (note the few scattered dentine-filled tubules (dark spots) in the root parts), (c) stereo distal view to show the interstitial facet for $\mathrm{m} / 1$ and the unabraded surface beneath it, (d) buccal view to show small pits but less abrasion overall than on the lingual surface.
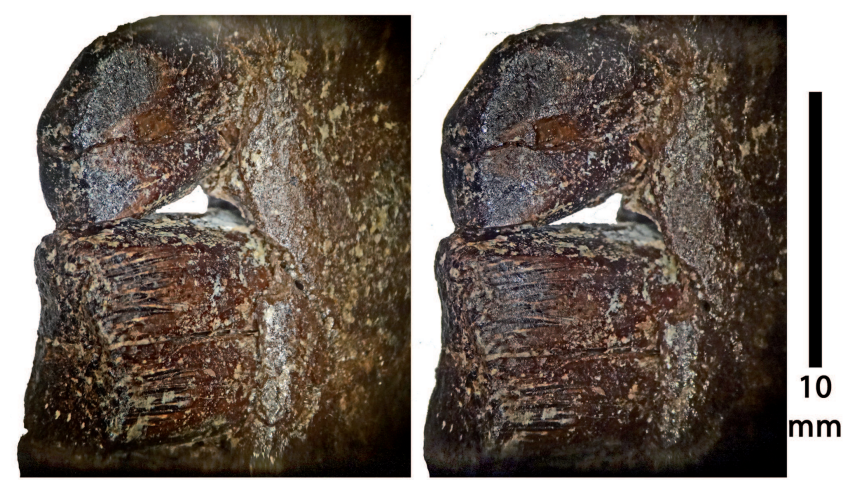

Figure 19. Oblique stereo view of the heavily abraded lingual and occlusal surfaces of the $\mathrm{p} / 4$ and $\mathrm{m} / 1$ in the holotype left mandible of Orycterochoerus alferezi gen. et sp. nov. from Córcoles, Spain. Compare the abundance of tubules infilled with dark dentine in the $\mathrm{m} / 1$ exposed due to removal of the cementum envelope by abrasion, with the paucity of tubules in the $\mathrm{p} / 4$.

the p/4 and P4/ are not affected in the same way because they were protected from the abrasive action of the food and tongue, the distal surface because it is inaccessible by its position between the tooth and the $\mathrm{m} / 1$ behind it, and the buccal surface because the tooth is concave on that side, and is therefore not exposed to contact with the food or tongue, or if it is, the abrasive action is weak to insignificant.
From this it is inferred that Orycterochoerus was consuming food items to which significant quantities of soil were adhering, in much the same way that the food of the aardvark, Orycteropus (termites, ants, fruits of Cucurbitaceae; Patterson, 1975) often contains soil particles which cause similar wear in the cheek teeth.

Post-cranial skeleton. There are two small suoid post-cranial bones from Córcoles which are of the right dimensions to belong to Orycterochoerus. A navicular (CO 5243 ) is slightly damaged along its outer edge, but what remains of the bone is similar to fossils of Bransatochoerus from Coderet (Pickford, 2016) and also Siderochoerus minimus from Petersbuch 2, Germany (MN 3) (Pickford, 2017). The talar facet is a concave hemi-cylinder and the facet for the cuneiform is slightly concave (Fig. 20).

The proximal epiphysis of an axial first phalanx (III or IV) is preserved (CO 5176) and shows a central groove continuous from dorsal to palmar edges as in Bransatochoerus, but deeper and broader than is usually the case in other Old World «Peccaries» (Pickford, 2017) (Fig. 20). The articular surfaces either side of the central groove are at different levels, as in Bransatochoerus and unlike the more evenly arranged surfaces that occur in suids such as Aureliachoerus (Pickford, 2016).

Body size. Pickford \& Hugueney (2018) estimated that the body weight of Bransatochoerus elaverensis from Coderet was about $50+/-19 \mathrm{~kg}$, based on comparisons with extant peccaries (Pecari tajacu) of known body weight $(22.5+/-8.5 \mathrm{~kg})$ which have a similar overall body plan. The lower third molars of Orycterochoerus alferezi and Lorancahyus hypsorhizus are half as long as those of Bransatochoerus elaverensis, and the mandible is smaller and shorter than those of Bransatochoerus, a relationship which suggests that the body weight of the Córcoles and Loranca species would have been appreciably lower than the one from Coderet. However, the $\mathrm{m} / 3 \mathrm{~s}$ are only slightly narrower than those of Bransatochoerus (mean $11 \mathrm{~mm}$ versus $9 \mathrm{~mm}$ in Lorancahyus daamsi and $7.5 \mathrm{~mm}$ in Orycterochoerus alferez) (Figs 21-22). In the absence of the talus and other remains that provide reliable information about body size, we are not in a position to calculate accurate body weights for the Córcoles species, but we estimate that it weighed in the region of $12-15 \mathrm{~kg}$.

Phylogenetic considerations. The recognition, within the broad category of Old World «Peccaries», of a clade with highly derived phalangeal and dental morphology prompts an analysis of the phylogeny of the group. The ancestral form was pentadactyl («1» in Fig. 23), had nonspatulate terminal phalanges, was bunodont with bilaterally fused roots in the lower molars (i.e., there were two transversely oriented roots, one supporting the protoconid and metaconid, the other supporting the entoconid and 

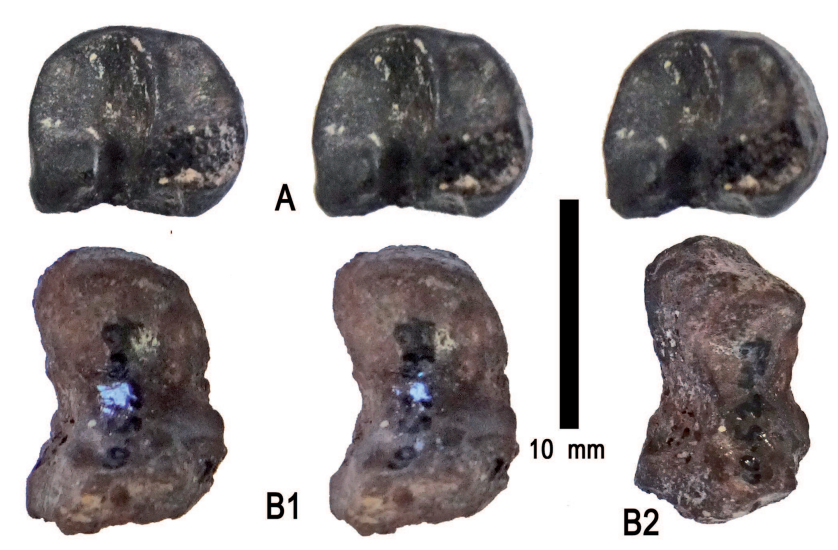

Figure 20. Post-cranial bones from Córcoles provisionally attributed to Orycterochoerus alferezi gen. et sp. nov. (a) CO 5243, stereo view of the articular surface of the proximal epiphysis of an axial phalanx. (b) CO 5176, left navicular (b1 - stereo talar view, b2 - oblique view of the part that articulates with the cuboid).

hypoconid), the lingual roots in the upper molars were coalescent, but the buccal ones were separated from each other, the upper and lower canines were implanted in the jaws vertically to sub-vertically, and the muzzle was long. The middle Oligocene genus Doliochoerus epitomises this plesiomorphic group.

One offshoot of this plesiomorphic clade lost the first metacarpal and thus became tetradactyl, at least in the manus («2» in Fig. 23 not discussed further in this article, but see Pickford (2017) for further details). The Orycterochoerinae retained pentadactyly but evolved spatulate terminal phalanges («3» in Fig. 23) in phase with the beginning of a trend to reduce the masticatory life of the molar crowns but to prolong the life of the molar roots which continued to erupt as the crowns were abraded away, thereby maintaining a level occlusal surface of the posterior cheek teeth despite heavy occlusal wear caused by ingestion of abrasive particles attached to the food. The next phase in the evolution of this group was the coalescence of the anterior and posterior roots of the lower cheek teeth to form a single column, but with two pulp cavities («4» in Fig. 23) accompanied by slight reduction of the hypoconulid of the $\mathrm{m} / 3$ and a diminution in body size. The next development was the evolution of randomly oriented tubular dentine in the cheek tooth roots («5» in Fig. 23) but with retention of a distinct pulp cavity in each root, accompanied by further reduction in the hypoconulid of the $\mathrm{m} / 3$ and of body dimensions. During this phase the roots of the P4/ still have two pulp cavities and the tooth is not greatly reduced in dimensions, and the lower molar root apices are slightly splayed apart. The next evolutionary development («6» in Fig. 23), shows the

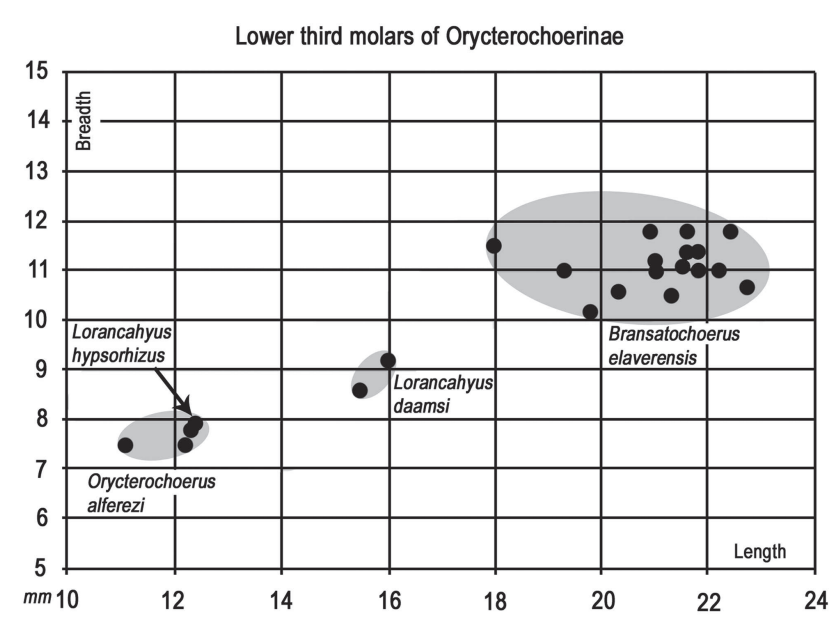

Figure 21. Bivariate plots of lower third molars of Orycterochoerinae subfam. nov. reveal that, as the lineage evolved, it became smaller and smaller (Bransatochoerus - MP30-MN0, Lorancahyus daamsi - MN 2, Lorancahyus hypsorhizus -MN 2, Orycterochoerus - MN4).

$\mathrm{P} 4 /$ reduced in dimensions and forming a single column with the pulp cavities eliminated, but the $\mathrm{p} / 4$ still possess two roots (without pulp cavities) completely enveloped in cementum to produce a single bucco-lingually compressed pillar. The molars in this phase show the pervasive presence of parallel to sub-parallel tubules infilled with dentine extending from the radicular apex to the occlusal surface, accompanied by further splaying out of the root apices within the mandible, reduction of the length of the muzzle, reduction in dimensions of the three anterior premolars, and the re-orientation of the canines to form a dihedral complex. The hypoconulid of the $m / 3$ is even further reduced, but the body size remains the same as in the preceding stage. The last phase was extinction.

The timing of these phases is approximately as follows : 1 - late Eocene to early and middle Oligocene, 2 - not well established, but already present in early Miocene forms (ca $22 \mathrm{Ma}$ ), 3 - late Oligocene (MP 30, ca $24 \mathrm{Ma}$ ), 4 - early Miocene (MN 2a, ca 22 Ma), 5 - early Miocene (MN 2b, ca $21 \mathrm{Ma}$ ), 6 - early Miocene (MN 4a, ca $17 \mathrm{Ma})$.

\section{DISCUSSION}

The discovery of Orycterochoerus gen. nov. is of major palaeontological interest, because it reveals in a dramatic way just how far convergent evolution can act in a few million years.

The earliest confidently attributed member of the subfamily Orycterochoerinae is Bransatochoerus elaverensis (Viret, 1928a, 1928b) from the late Oligocene 

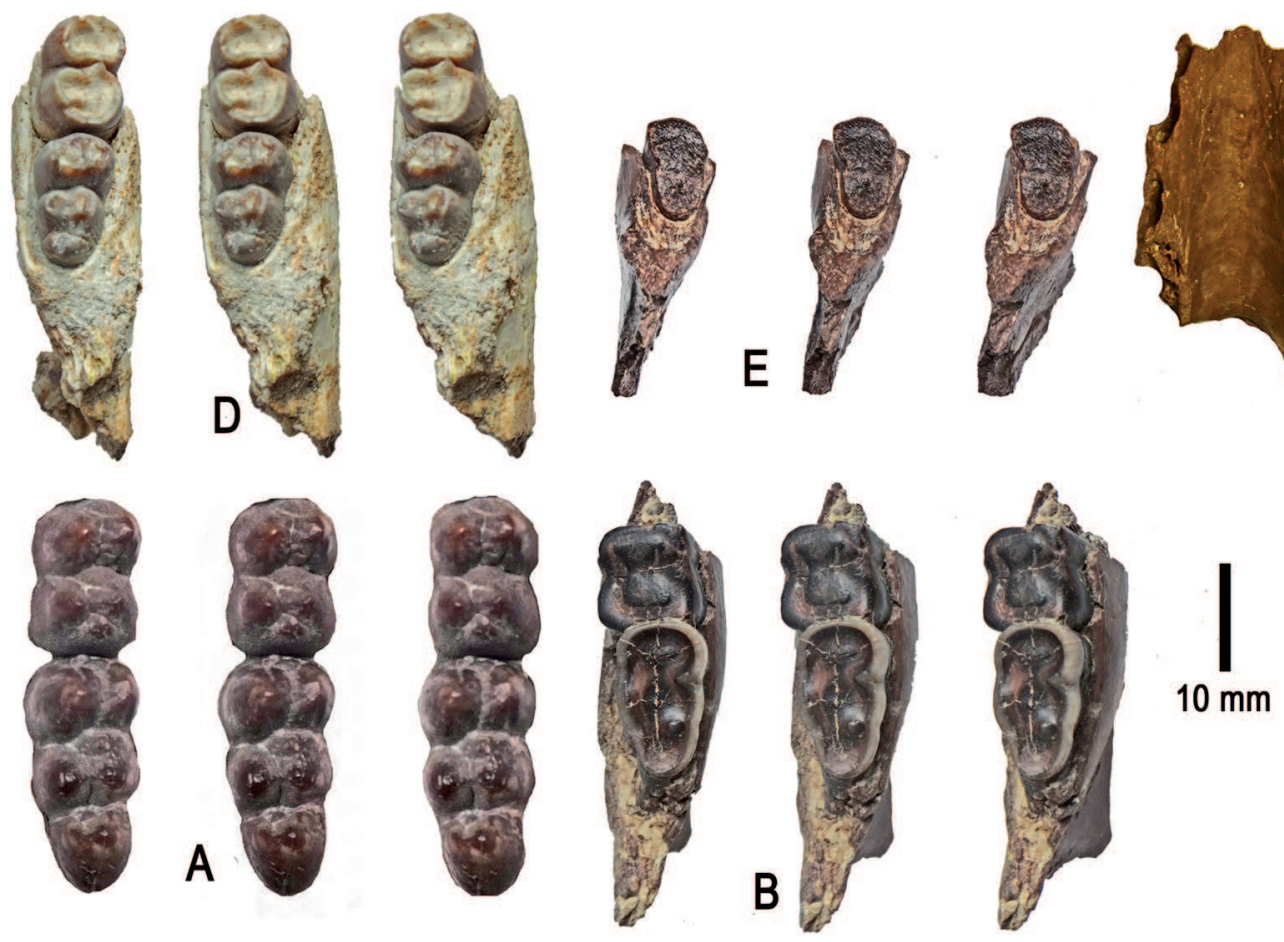

Figure 22. Comparison of $\mathrm{m} / 3 \mathrm{~s}$ of Orycterochoerinae to show evolutionary changes in dimensions and crown morphology. The earliest member of the lineage, Bransatochoerus elaverensis (a) (MP 30) was the largest species, and had well-developed enamelcovered molar crowns with classic suoid cusp morphology. Lorancahyus daamsi from Moheda (b), from Montaigu-leBlin (c) (MN 2a) was somewhat smaller ( $\mathrm{m} / 3$ length ca $75 \%$ of that of B. elaverensis) and its molar crowns were enamelcovered but with a tendency for the crowns to wear away leaving a ring of enamel surrounding a massive dentine occlusal surface. Lorancahyus hypsorhizus (d) (MN 2b) was about 50\% the size of B. elaverensis, the cusp structure of its enamelcovered molar crown being extremely simplified, and its dentine partly tubular. Orycterochoerus alferezi (e) (MN 4a) is similar in dimensions to Lorancahyus hypsorhizus, but it seems from the available fossils that, either the crowns were devoid of enamel, or if they had enamel it was worn away at a juvenile ontogenetic stage, leaving the occlusal surface enamel-free and comprised of a dense network of dentine tubules.

(ca $24 \mathrm{Ma}$ ) of France and Germany (Pickford, 2017) which retains well-formed enamel caps on the cheek teeth, but already shows precocious wear of the crowns, strong fusion of the roots and roots that continue to erupt after maturity is reached, such that heavily worn teeth still have the occlusal surface at the same level as the rest of the cheek tooth battery (Pickford \& Hugueney, 2018). The dentine of the roots of the cheek teeth of Bransatochoerus does not appear to have any tubules but there are large pulp cavities as is usual in suiformes. In contrast, the molars of the geologically younger species Lorancahyus daamsi and Lorancahyus hypsorhizus (from Moheda (22 Ma) and Loranca (21 Ma) respectively, MN 2) possess similarly strongly fused roots which are tall, and Lorancahus hypsorhizus has dispersed dentine-filled tubules arranged in various directions (Pickford, 1993; Pickford \& Morales, 1998). The molar roots of both these species have large pulp cavities. In contrast Orycterochoerus, which is ca 17 $\mathrm{Ma}$, has pillar-like roots but no large pulp cavities remain, and the bulk of the tooth is comprised of closely packed, sub-parallel, vertical tubules infilled with dentine. These tubules represent a multitude of narrow pulp cavities. The available sample of teeth of this genus is restricted, but none of the molars shows any evidence of an enamel cap, unlike the canine, the $p / 2, p / 3$ and $p / 4$ which do have enamel-covered crowns, although that of the $p / 4$ is soon eradicated by heavy occlusal wear. The fact that the $\mathrm{p} / 4$ has an enamel cap which is worn away early during ontogeny suggests that the molars of juveniles may also have possessed enamel caps but that these were soon worn away leaving only the roots as the functional part for most of the sub-adult and adult life phases of the individuals.

The posterior cheek teeth of the genus Orycterochoerus thereby superficially resemble the teeth of the aardvark, as was pointed out on several occasions by Alférez et al. (1988a, 1988b, 1999) (Fig. 10) but the anterior ones do not. Thus, over a period of about seven million years, a suoid lineage with relatively unspecialised cheek teeth developed tubulidentate, hypselorhizic teeth that so closely resemble those of the order Tubulidentata, that for thirty years its discoverers classified it as an aardvark and drew invalid biogeographic inferences from its presence in Spain during 


\section{DOLIOCHOERINAE} ORYCTEROCHOERINAE

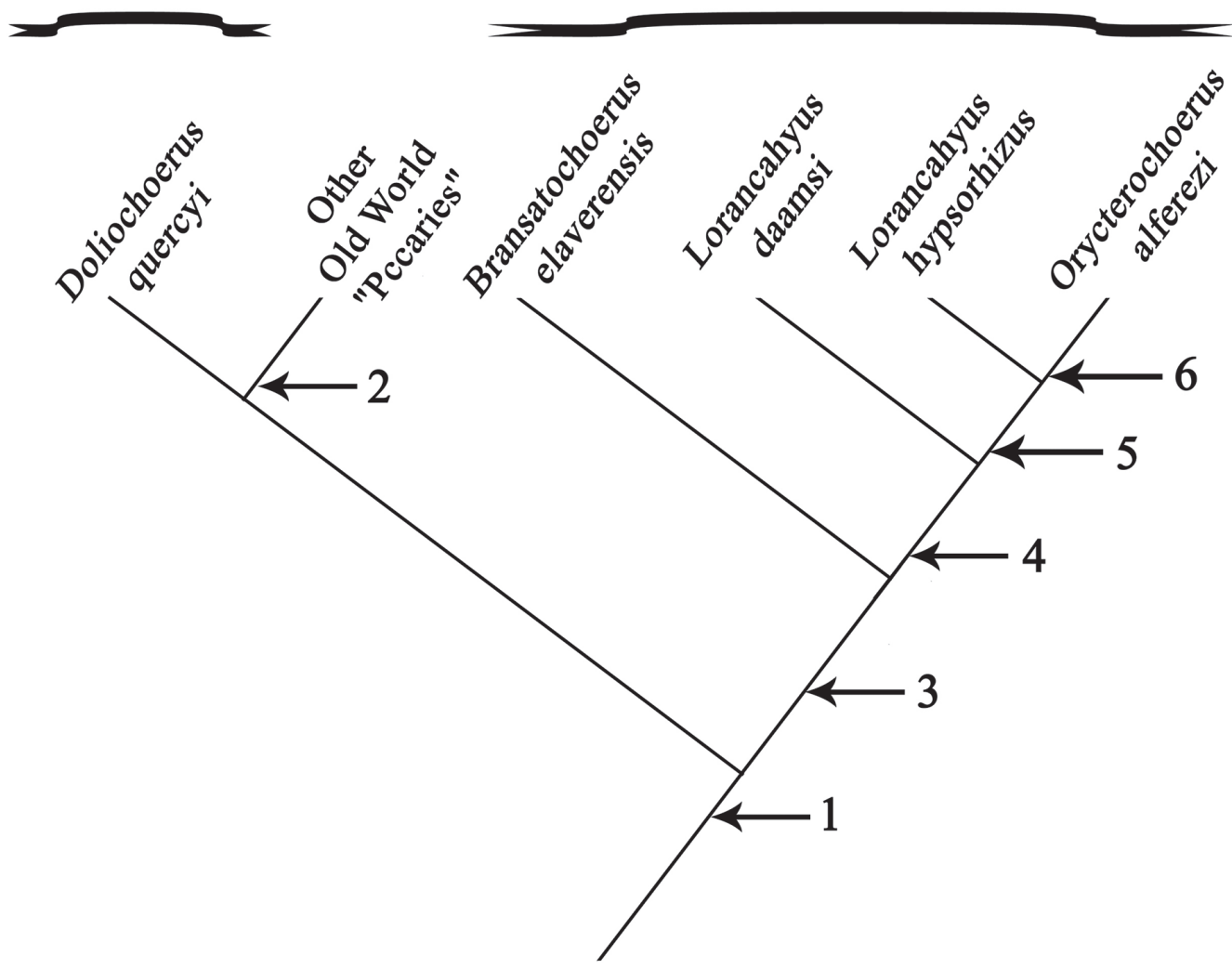

Figure 23. Phylogenetic hypothesis of some Old World « Peccaries » focussing on Orycterochoerinae subfam. nov., which eventually evolved tubulidentate, hypselorhizic cheek teeth that resemble those of the Order Tubulidentata. [1 - pentadactyly, bunodont cheek teeth, bilaterally fused lower molar roots, lingual roots in upper molars coalescent, buccal roots in upper molars separated from each other, cheek tooth roots taper markedly towards their apices, upper and lower canines steeply inserted in jaws, muzzle long; 2 - loss of metacarpal I (= tetradactyly); 3 - reduction of cheek tooth crown life, prolongation of root eruption (maintainance of occlusal surface of teeth at the same level as the other teeth despite heavy wear) development of spatulate terminal phalanges in the manus and pes; 4 - hypsorhizy (coalescence of anterior and posterior roots of the lower molars, with retention of two pulp cavities, prolonged eruption of cheek tooth roots, further abbreviation of crown life); 5 - tubulidenty (development of dentine-filled tubules, tubules randomly oriented, pulp cavities still present in roots), molar root apices beginning to splay apart; 6 - hypselorhizy (elimination of pulp cavities in the roots of $\mathrm{p} / 4-\mathrm{m} / 3$ and $\mathrm{P} 4 /-\mathrm{M} 3 /$, pervasive development in the cheek tooth roots of tubules infilled with dentine extending from the radicular apex to the occlusal surface, reduced tapering of the roots towards their apices, life-long root growth and eruption, no signs of enamel caps in cheek teeth) accompanied by shortening of the muzzle (Fig. 24), reduction in dimensions of the anterior premolars, splaying apart of the lower canines (dihedral angle of ca $60^{\circ}$ )].

the early Miocene much earlier than any other record of the presence of Tubulidentata in Eurasia (Pickford, 1975).

In various papers, Pickford (1993, 2016, 2017; Pickford \& Morales, 1998) pointed out the presence of heavy occlusal wear in the teeth of Lorancahyus and the same was eventually shown to be the case with Bransatochoerus (Pickford \& Hugueney, 2018). These authors stressed the fact that the occlusal surface of worn cheek teeth remained at the general level of the occlusal surface of the cheek tooth battery, from which they inferred that there was continuous lifelong eruption of the roots, a feature not known to occur in any other suoid, and labelled «hypsorhizy» by the authors. Hypsorhizy prolongs the masticatory life of the cheek teeth, compensating for excessive occlusal wear of the teeth by extending the eruptive life of the roots well into maturity of the individual, and perhaps even into senility. In much the same way, hypsodonty in suids such as the Wart Hog (Phacochoerus) extends the masticatory life of the cheek teeth by increasing the height of the crowns of the molars which continue to erupt until senility sets in (Pickford \& Gommery, 2016, and references therein). 


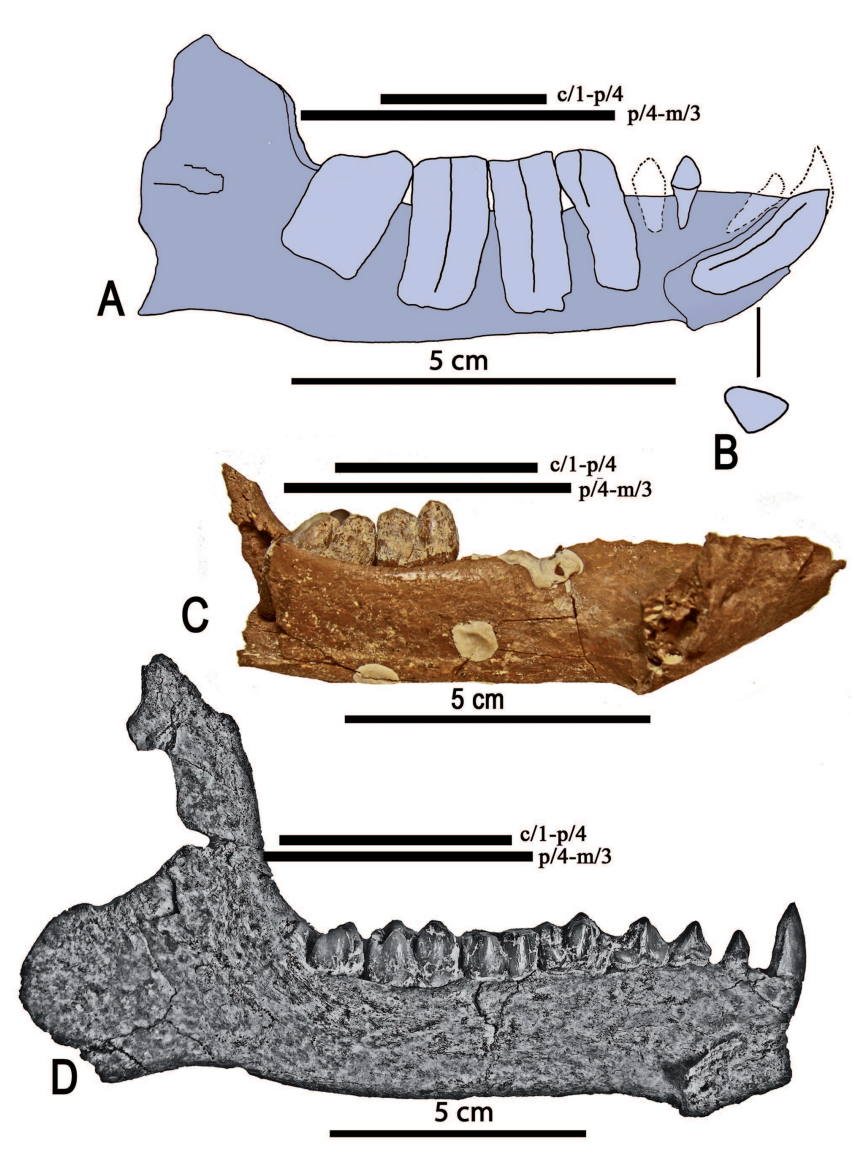

Figure 24. Comparison of mandibles of Orycterochoerus alferezi gen. et sp. nov. from Córcoles, Spain (drawing from an X-ray image) (a), Lorancahyus daamsi from Montaigu-le-Blin (image reversed) (c) and Bransatochoerus elaverensis (d) from Coderet, France (image reversed) to show the major differences in muzzle lengths as shown in the black bars above the tooth rows : reduced length of $\mathrm{c} / 1-\mathrm{p} / 4$ relative to length of $\mathrm{p} / 4-\mathrm{m} / 3$ in Orycterochoerus $52.8 \%$ ) intermediate in Lorancahyus daamsi $(70.7 \%)$ and elongated in Bransatochoerus (86.3\%). Note the splayed out arrangement of the molars in Orycterochoerus, and their more vertical orientation in Bransatochoerus. Note also the enamel cap present in the $\mathrm{p} / 2$ and the canine (present in the right mandible fragment) of Orycterochoerus; (b) shows the scrofic section of the left canine of Orycterochoerus.

The differences between hypsorhizy and hypsodonty are manifest, as the first emphasises the roots and deemphasises the enamel-covered crown whereas the second emphasises the crown and eventually eliminates the roots. From a morpho-functional perspective, the differences between hyposorhizy and hypsodonty appear to be related to the cause of the excessive occlusal abrasion to which the teeth are exposed. In the former, it is likely that excessive wear is due to ingestion of soil particles adherant to the ingested food, while in the latter it is the presence of phytoliths in the food. Soil particles tend to produce large pits and scratches in the surface of the tooth, and will occasionally result in major damage to the tooth such as the spalling away of chunks of enamel or flakes of dentine. Opal phytoliths are much smaller and abrade the occlusal surface more evenly without producing large scars, pits and scratches, but effectively wear away the surface of the crown more rapidly than food items such as fruit and leaves that possess few phytoliths or none at all.

Over evolutionary time, there is selection for dental structures that will compensate for excessive occlusal wear. When the damage is due to soil particles, it is the roots that fulfil the role of prolonging the occlusal life of the teeth, and eventually the internal structure of the roots becomes reinforced by the development of tubules infilled with dentine, which aid in mitigating serious damage due to the spalling away of tooth mass by dispersing the chewing forces away from the point of impact with grit in the ingested soil. In the case of diets rich in opal phytoliths, it is the crown that fulfils the role of prolonging the occlusal life of the teeth, which is thereby selected to be taller and thus longer-lasting. In extreme cases, natural selection can result in hypselorhizy and hypselodonty, meaning that the teeth become ever-growing, in the former case it is the root that continues growing throughout life, in the latter it is the crown that continues growing. The main difference between these tooth categories is that hypselorhizic teeth have no enamel (except perhaps during the infant and/ or juvenile stage of ontogeny) and they have no pulp cavities, whereas hypselodont teeth possess enamel even into senility and they retain pulp cavities throughout life.

The observation that since the Cretaceous many lineages of mammals independently evolved hypsorhizic or hypsodont teeth indicates that natural selection has repeatedly acted in the same sense to produce fine examples of parallel and convergent evolution. The present study provides yet another instance of convergent evolution, this time between a suoid artiodactyl (Orycterochoerus) and a tubulidentate (Orycteropus), members of two radically different orders of mammals that survived on different continents but which were contemporaries for several million years.

Finally, the rate of evolution of tubulidentate hypselorhizic cheek teeth in the Orycterochoerinae (achieved over a period of less than $7 \mathrm{Ma}$, and most likely within a period of ca $5 \mathrm{Ma}$, starting from a bunodont, enamel-covered molar morphology typical of Suoidea) prompts a reconsideration of the evolution of the aarvark. Long thought to have an immensely long «ghost» lineage, the origins of the aardvark (Order Tubulidentata) are still a matter of speculation. Patterson (1975) postulated an origin from an unknown predecessor which lived in the Palaeocene, which implies a ghost lineage extending over a period of nearly 40 million years until the early Miocene where the earliest known fossils have been found (Pickford, 1975). 
Among Afrotheria, Lehmann (2009) recovered sister-group relationships of Orycteropodidae (Macroscelididae, with Chrysochloridae and Hyracoidea more remotely positioned) but none of the Afrotheria possess an astragalar foramen which, in our opinion, weakens the results. Lehmann (2009) did not investigate phylogenetic relationships at a higher supraordinal systematic level due to difficulties in selecting a suitable out-group.

The earliest record of the order Tubulidentata is Orycteropus minutus from Songhor, Kenya, of early Miocene age (ca $20 \mathrm{Ma}$, Pickford, 1975). If the tubulidentate hypselorhizic teeth of the order evolved as rapidly as those of Orycterochoerinae, then searches for the origins of the order among the early Oligocene or older faunas of Africa would tend to be fruitless if only dental characters are examined. More reliable would be non-dental characters such as the presence of an unfused mandibular symphysis, nasal bones with an encoche in the anterior end of each bone, and a talus with an astragalar foramen among other post-cranial characters. Resolution of the origins of the aardvark is not the aim of this paper but it is noted that genera such as Ptolemaia (Eocene-Oligocene of the Fayum, Egypt) or Kelba (early Miocene of East Africa) are unlikely to be related to orycteropodids despite suggestions to the contrary (Gunnell et al., 2010; Cote et al., 2007).

\section{CONCLUSIONS}

Detailed examination of fossils from early Miocene deposits at Córcoles, Spain, previously attributed to Tubulidentata (the order to which extant aardvarks belong) by Alférez et al. (1988a, 1988b, 1999) reveals that the specimens represent a suoid with affinities to Doliochoeridae, a family that is well-represented in the Oligocene-Miocene of Eurasia (Pickford, 2011, 2016, 2017). The dental peculiarities that led to the attribution of the Córcoles material to Tubulidentata are spectacular, the posterior cheek teeth being hypselorhizic with a well-developed sub-parallel, vertical tubular internal microstruture and no pulp cavity, the ensemble being enveloped in a sheath of cementum. Found in isolation these teeth could easily be confused with those of aardvarks (Alferéz et al., 1988a), so close is their superficial appearance to that of antbear teeth, but examination under the microscope reveals differences in the internal morphology of the tubular structures (Fig. 10), the disposition of the tubules within the teeth and the 8 -shaped occlusal outline which is considerably weaker in the Córcoles fossils than it is in extant aardvarks and their extinct relatives.

The mandible from Córcoles, which has four tubulidentate teeth in situ, also has two anterior teeth preserved which are typical of the superfamily Suoidea, comprising a tall slightly outwardly splayed lower canine of scrofic section and a pointed enamel-covered crown, and a $\mathrm{p} / 2$ which has an enamel-covered crown posed on a single root. In addition, the jaw preserves an incisor alveolus, as well as alveoli for the $\mathrm{p} / 1$ and $\mathrm{p} / 3$, indicating a post-canine dental formula of four premolars and three molars. The jaw also shows that the four posterior teeth are splayed out in the jaw, their occlusal surfaces touching each other, but with their radicular apices well-separated from each other. The mandibular symphysis is fused. In aardvarks in contrast, the mandibular symphysis is unfused, the dental formula is different, there is no caniniform tooth and the posterior teeth are oriented in the jaw sub-parallel to each other and in many individuals there is no contact between neighbouring teeth (Pickford, 1975).

Another significant difference between the Córcoles suoid and aardvarks concerns the length of the muzzle, which is abbreviated in Orycterochoerus (c/1-p/4 is considerably shorter than $\mathrm{p} / 4-\mathrm{m} / 3$ ) and is elongated in aardvarks $(\mathrm{c} / 1-\mathrm{p} / 4$ is appreciably longer than $\mathrm{p} / 4-\mathrm{m} / 3)$ (Pickford, 1975).

The manifest differences between the Córcoles suoid and related suoid genera (Bransatochoerus and Lorancahyus) indicate that it represents a new genus and species, herein named Orycterochoerus alferezi, in reference to the superficial similarities that its tubulidentate teeth share with those of aardvarks, and in honour of the person who excavated the fossils. Despite the differences that Orycterochoerus shows from Bransatochoerus from the late Oligocene, and Lorancahyus from the basal Miocene, it evidently belongs to the same evolutionary lineage, being its youngest and morphologically most derived known representative. The three genera are herein grouped into a newly diagnosed subfamily, the Orycterochoerinae.

The evolution of the Orycterochoerinae subfam. nov. played out over a time span of about $7 \mathrm{Ma}$ (MP 30, ca $24 \mathrm{Ma}$ to $\mathrm{MN} 4$, ca $17 \mathrm{Ma}$ ) after which the lineage seems to have gone extinct, it being unknown from deposits correlated to MN 5 or younger biozones. The rate of evolutionary change was exceptionally rapid when compared with the slower and much more moderate morphological changes that occurred in other members of the family Doliochoeridae from the Oligocene to the late Miocene (Pickford, 2017). As such, the Orycterochoerinae are highly unusual among Suoidea as is the fact that the subfamily seems to have been restricted in its distribution to Western Europe (Germany, France, Spain) throughout its tenure.

Finally, it is postulated that members of the new subfamily Orycterochoerinae used their feet to dig in the ground: the terminal phalanges in the manus and pes of Bransatochoerus are Orycteropus-like (Pickford \& Hugueney, 2018). The condition of the phalanges is unknown in Lorancahyus and Orycterochoerus because few post-cranial bones of these taxa have have been recognised. It is inferred that the 
spatulate terminal phalanges of Bransatochoerus imply that the animal gained access to underground food resources or excavated burrows in which to shelter (or both), and that, like aardvarks, they ingested sufficient soil adherant to their food to influence the course of natural selection which eventually culminated in the evolution of hypselorhizic cheek teeth with tubular internal structure.

\section{ACKNOWLEDGEMENTS}

Juan Carlos Gutiérrez Marcos (Universidad Complutense, Madrid) kindly put the material from Córcoles at our disposal. Concha Herrero (Área de Paleontología, Dpto. Geodinámica, Estratigrafía y Paleontología, F.CC. Geológicas) provided access to the Córcoles collections under her care. Thanks to Silvia Menéndez and Victoria Quiralte for access to fossils housed at the MGM. Susana Fraile provided access to fossils at the MNCN. Special thanks to Pablo Peláez-Campomanes for his help at all times. We thank CR2P/UMR 7207 - Sorbonne Université - MNHN, CNRS, UPMC, Université Paris VI, for support, while The Spanish Research Project CGL2015-68333-P (MINECO/FEDER-UE) and the Research Groups CSIC 641538 and CAM-UCM 910607 funded aspects of this research. The Córcoles fossils were excavated by Dr. Francisco Alférez and his collaborators. Scanner images were prepared by Servicio de Técnicas No Destructivas: Microscopía Electrónica y Confocal y Espectroscopía del MNCM-CSIC.

\section{REFERENCES}

Alférez, F. \& Brea, P. 1981. Estudio preliminar de los restos de Peces, Anfibios y Reptiles del yacimiento mioceno de Córcoles (Guadalajara). Boletín del Real Sociedad Española de Historia Natural (Geología), 79, 5-20.

Alférez, F., Villalta, J.F. \& Moyà-Solà, S. 1981. Primera cita en España del antílope más antiguo de Europa, Eotragus artenensis, Ginsburg \& Heinz, 1968 (Mammalia, Bovidae), procedente del Orleaniense de Córcoles (Guadalajara). Revista COL-PA, (Coloquios de Paleontología), 36, 41-51.

Alférez, F., Molero, G., Brea, P. \& Santafé, J.V. 1982. Precisiones sobre la geología, fauna, cronoestratigrafía y paleoecología del yacimiento Mioceno de Córcoles. Revista de la Real Academia de Ciencias Exactas, Físicas y Naturales de Madrid, 76, 249-276.

Alférez, F., Gutiérrez, G.M., Dias, E.M., Vega, C.I., Marcos, I.T. \& Mediavilla, I.M. 1988a. La Alcarria y su fauna hace 18 millones de años. Departamento de Paleontología, Universidad Complutense de Madrid, Publicación n 467, $8 \mathrm{pp}$.
Alférez, F., Molero, G., Maldonado, E. \& Íñigo, C. 1988b. Los restos fósiles más antiguos de Orycteropidae (sic) (Tubilidentata (sic), Mammalia) hallados in Eurasia. Coloquio Homenaje a Rafael Adrover, "Bioeventos y Sucesiones faunísticas en el Terciario continental Ibérico", Sabadell, 7.

Alférez, F., Íñigo, C., Molero, G. \& Maldonado, E. 1999. El registro fósil de Córcoles (Guadalajara), España: Reflejo de la vida en la Alcarria en el Mioceno inferior. In: La Huella del Pasado fósiles de Castilla-La Mancha (Coords. Aguirre, E. \& Rábano, I.). Patrimonio HistóricoArqueología Castilla-La Mancha, Toledo, 263-273.

Álvarez-Sierra, M.A., Daams, R. \& Peláez-Campomanes, P. 1994. Synthesis of Late Oligocene/Early Miocene micromammal faunas of the Loranca Basin (Province of Cuenca, Spain). Comunicaciones de las X Jornadas de Paleontología, pp. 18-21.

Álvarez-Sierra, M.A., García Paredes, I., Van den Hoek Ostende, L., Van der Meulen, A.J., Peláez-Campomanes, P. \& Sevilla, P. 2006. The Middle Aragonian (Middle Miocene) Micromammals from La Retama (Intermediate Depression, Tagus Basin) Province of Cuenca, Spain. Estudios Geológicos, 62, 401-428; doi: 10.3989/ egeol.0662135.

Cote, S., Werdelin, L., Seiffert, E.R. \& Barry J.C. 2007. Additional material of the enigmatic early Miocene mammal Kelba and its relationship to the order Ptolemaiida. Proceedings of the National Academy of Sciences, USA, 104, 5510-5515; doi: 10.1073/pnas.0700441104.

Crespo, V.D. 2017. Los mamíferos del Mioceno inferior de la cuenca de Ribesalbes-Alcora (Castelló, España). Ph.D. Thesis, University of Valencia. 695 pp.

Crusafont, M. \& Quintero, I. 1970. Noticia preliminar acerca de un nuevo yacimiento de mamíferos fósiles de la provincia de Guadalajara. Acta Geologica Hispanica, 5, 102-104.

Daams, R. 1990. Hypsodont Myomiminae (Gliridae, Rodentia) from the Miocene and the Oligocene-Miocene boundary interval of Spain. Scripta Geologica, 95,1-62.

Daams, R., Lacomba, J.I. \& López-Martínez, N. 1986. Nuevas faunas de Micromamíferos del Terciario continental de la Depresión Intermedia (provincia de Cuenca, España centro-oriental). Estudios Geológicos, 42, 181-196; doi: 10.3989/egeol.86422-3.

De Bruijn, H. Daams, R. Daxner-Höck, G., Fahlbusch, V., Ginsburg, L., Mein, P. \& Morales, J. 1992. Report of the RCMNS working group on fossil mammals, Reisensberg 1990. Newsletters in Stratgraphy, 26, 65-118; doi: $10.1127 / \mathrm{nos} / 26 / 1992 / 65$.

Díaz Molina, M. \& López Martínez, N. 1979. El Terciario continental de la Depresión Intermedia (Cuenca). Bioestratigrafía y Paleogeografía. Estudios Geológicos, 35, 149-167.

Freudenthal, M. 2006. The status of Democricetodon, Fahlbuschia, Pseudofahlbuschia and Renzimys (Cricetidae, Mammalia). A reply to Van der Meulen et al. (2004). Geobios, 39, 43-55; doi: 10.1016/j.geobios.2004.08.005. 
García-Paredes, I., Peláez-Campomanes, P. \& Álvarez-Sierra, M.A. 2009. Gliridae (Rodentia, Mammalia) with a simple dental pattern: a new genus and new species from the European Early and Middle Miocene. Zoological Journal of the Linnean Society, 157, 622-652; doi: 10.1111/j.10963642.2009.00527.x.

Gray, J.E. 1821. On the natural arrangement of vertebrose animals. London Medical Repository, 15, 296-310.

Gunnell, G.F., Gingerich, P.D. \& Holroyd, P.A. 2010. Ptolemaiida. In: Cenozoic Mammals of Africa, (eds Werdelin, L. \& Sanders, W.J.). University of California Press, pp. 83-87.

Íñigo, C. 1993. Estudio de los Perisodáctilos del yacimiento Mioceno de Córcoles (Guadalajara). Ph.D. Thesis, Universidad Complutense de Madrid, 559 pp.

Íñigo, C. 1994. Protaceratherium platyodon (Rhinocerotidae, Mammalia) del yacimiento Mioceno de Córcoles (Guadalajara, España). Estudios Geológicos, 50, 247-252; doi: 10.3989/egeol.94503-4322.

Íñigo, C. 1995. Diversidad métrica en Anchitherium (Equidae, Mammalia) y paleoecosistemas asociados. XI Jornadas de Paleontología, 103-105.

Íñigo, C. 1997. Anchitherium corcolense nov. sp., a new anchitherine (Equidae, Mammalia) from the early Aragonian site of Córcoles (Guadalajara, Spain). Geobios, 30, 849-869; doi: 10.1016/S0016-6995(97)80186-6.

Íñigo, C. \& Cerdeño, E. 1997. The Hispanotherium matritense (Rhinocerotidae) from Córcoles (Guadalajara, Spain): its contribution to the systematics of the Miocene Elasmotherini. Geobios, 30, 243-266; doi: 10.1016/ S001669959780232X.

Lehmann, T. 2009. Phylogeny and systematics of the Orycteropodidae (Mammalia, Tubulidentata). Zoological Journal of the Linnaean Society, 155, 649-702; doi: 10.1111/j.1096-3642.2008.00460.x.

Maldonado, E. \& Alférez, F. 1990. Nuevos restos de Gomphotherium (Proboscidea, Mammalia) del Aragoniense medio de Córcoles (Guadalajara). Acta Salmanticensia, 68, 217-223.

Maldonado, E., Mazo, A. \& Alférez, F. 1983. Los mastodontes (Proboscidea, Mammalia) del Orleaniense medio de Córcoles (Guadalajara). Estudios Geológicos, 39, 431-449.

Morales, J., Nieto, M., Peláez-Campomanes, P., Soria, D., Álvarez, M., Alcalá, L., Amezua, L., Azanza, B., Cerdeño, E., Daams, R., Fraile, S., Guillem, J., Hoyos, M., Merino, L., de Miguel, I., Monparler, R., Montoya, P., Pérez, B., Salesa, M. \& Sánchez, I. 1999. Vertebrados continentales del Terciario de la Cuenca de Loranca (Provincia de Cuenca). In: La Huella del Pasado fósiles de Castilla-La Mancha (Coords Aguirre, E. \& Rabano, I.). Patrimonio Histórico-Arqueología Castilla-La Mancha, 237-260.

Moyà-Solà, S. \& Alférez, F. 1988. Los rumiantes (Mammalia) del Mioceno inferior de Córcoles (Guadalajara): su posición dentro de las faunas del Aragoniense inferior de España. Coloquio Homenaje a Rafael Adrover, "Bioeventos y Sucesiones faunísticas en el Terciario continental Ibérico", Sabadell, 26.
Oliver, A. \& Peláez-Campomanes, P. 2014. Evolutionary patterns of early and middle Aragonian (Miocene) of Megacricetodon (Rodentia, Mammalia) from Spain. Palaeontographica, Abteilung A: PalaeozoologyStratigraphy, 303, 85-135; doi: 10.1127/pala/303/2014/85.

Orliac, M. 2006. Eurolistriodon tenarezensis sp. nov. from Montreal-du-Gers (France): Implications for the systematics of the European Listriodontinae (Suidae, Mammalia). Journal of Vertebrate Paleontology, 26, 967980; doi: 10.1671/0272-4634.

Owen, R. 1848. Description of teeth and portions of jaws of two extinct anthracotheroid quadrapeds (Hyopotamus vectianus and $H$. bovinus) discovered by the Marchioness of Hastings in the Eocene deposits on the N.W. coast of the Isle of Wight, with an attempt to develop Cuvier's idea of the classification of pachyderms by the number of their toes. Quarterly Journal of the Geological Society of London, 4, 103-141.

Patterson, B. 1975. The fossil Aardvarks (Mammalia, Tubulidentata). Bulletin of the Museum of Comparative Zoology, 147, 185-237.

Pickford, M. 1975. New fossil Orycteropodidae (Mammalia, Tubulidentata) from East Africa. Netherlands Journal of Zoology, 25, 57-88.

Pickford, M. 1993. Old World Suoid systematics, phylogeny, biogeography and biostratigraphy. Paleontologia $i$ Evolucio, 26-27, 237-269.

Pickford, M. 2011. Small suoids from the Miocene of Europe and Asia. Estudios Geológicos, 67, 541-578; doi: 10.3989/ egeol.40634.206.

Pickford, M. 2016. Revision of European Hyotheriinae (Suidae) and Doliochoeridae. Münchner Geowissenschaftliche Abhandlungen, Reihe A, Geologie und Paläontologie, 44, 1-270.

Pickford, M. 2017. Revision of «peccary-like» Suoidea (Artiodactyla: Mammalia) from the Neogene of the Old World. Münchner Geowissenschaftliche Abhandlungen, Reihe A, Geologie und Paläontologie, 46, 1-144.

Pickford, M. \& Gommery, D. 2016. Fossil Suidae (Artiodactyla, Mammalia) from Aves Cave I and nearby sites in Bolt's Farm Palaeokarst System, South Africa. Estudios Geologicos, 72, 24; doi: 10.3989/egeol.42389.404.

Pickford, M. \& Hugueney, M. (2018). Bransatochoerus (Suoidea: Mammalia) from the late Oligocene of Coderet (Bransat, Allier, France): osteology, diet and growth variables. Revue de Paléobiologie, 37.

Pickford, M. \& Morales, J. 1994. Biostratigraphy and palaeobiogeography of East Africa and the Iberian Peninsula. Palaeogeography, Palaeoclimatology, Palaeoecology, 112, 297-322; doi: 10.1016/00310182(94)90078-7.

Pickford, M. \& Morales, J. 1998. A tubulidentate suiform lineage (Tayassuidae, Mammalia) from the early Miocene of Spain. Comptes Rendus de l'Académie de Science, Paris, 327, 285-290; doi: 10.1016/S1251-8050(98)80087-6.

Pickford, M. \& Morales, J. 2003. New Listriodontinae (Suidae, Mammalia) from Europe and a review of 
listriodont evolution, biostratigraphy and biogeography. Geodiversitas, 25, 347-404.

Pickford, M. \& Moyà-Solà, S. 1995. Eurolistriodon gen. nov. (Suoidea, Mammalia) from Els Cassots, early middle Miocene, Spain. Proceedings of the Koninklijke Nederlandse Akademie van Wetenschappen, 98, 343-360.

Simpson, G.G. 1945. The principals of classification and a classification of mammals. Bulletin of the American Museum of Natural History, 85, 1-350.

Van der Made, J. \& Alférez, F. 1988. Dos suidos bunodontos (Listriodontinae) del Mioceno inferior de Córcoles (Guadalajara, España). Coloquio Homenaje a Rafael
Adrover, "Bioeventos y Sucesiones faunísticas en el Terciario continental Ibérico", 22.

Van der Meulen, A.J. Peláez-Campomanes, P. \& Daams, R. 2003. Revision of medium-sized Cricetidae from the Miocene of the Daroca-Villafeliche area in the Calatayud-Teruel basin (Zaragoza, Spain). Coloquios Paleontologicos, Volume Extra 1, 385-441.

Viret J. 1928a. Sur la faune oligocène de Coderet près Branssat (Allier). Comptes rendus des séances de l'Académie des Sciences, Paris, 186, 1309-1311.

Viret J. 1928b. Les faunes de mammifères de l'Oligocène supérieur de la Limagne bourbonnaise. Thèse Doctorat ès Sciences naturelles, Lyon, 328 pp. 
